\title{
The Coupling between $\mathrm{Ca}^{2+}$ Channels and the Exocytotic $\mathrm{Ca}^{2+}$ Sensor at Hair Cell Ribbon Synapses Varies Tonotopically along the Mature Cochlea
}

\author{
(1)Stuart L. Johnson, ${ }^{1 *}$ () Jennifer Olt, ${ }^{1 *}$ Soyoun Cho, ${ }^{2,3 *}{ }^{-}$Henrique von Gersdorff, ${ }^{2}$ and ${ }^{\circ}$ Walter Marcotti ${ }^{1}$ \\ ${ }^{1}$ Department of Biomedical Science, University of Sheffield, Sheffield S10 2TN, United Kingdom, ${ }^{2}$ Vollum Institute, Oregon Health \& Science University, \\ Portland, Oregon 97239, and ${ }^{3}$ Center for Sensory Neuroscience, Boys Town National Research Hospital, Omaha, Nebraska 68131
}

The cochlea processes auditory signals over a wide range of frequencies and intensities. However, the transfer characteristics at hair cell ribbon synapses are still poorly understood at different frequency locations along the cochlea. Using recordings from mature gerbils, we report here a surprisingly strong block of exocytosis by the slow $\mathrm{Ca}^{2+}$ buffer EGTA $(10 \mathrm{mM})$ in basal hair cells tuned to high frequencies $(\sim 30 \mathrm{kHz})$. In addition, using recordings from gerbil, mouse, and bullfrog auditory organs, we find that the spatial coupling between $\mathrm{Ca}^{2+}$ influx and exocytosis changes from nanodomain in low-frequency tuned hair cells $(\sim<2 \mathrm{kHz})$ to progressively more microdomain in high-frequency cells $(\sim>2 \mathrm{kHz})$. Hair cell synapses have thus developed remarkable frequency-dependent tuning of exocytosis: accurate low-latency encoding of onset and offset of sound intensity in the cochlea's base and submillisecond encoding of membrane receptor potential fluctuations in the apex for precise phase-locking to sound signals. We also found that synaptic vesicle pool recovery from depletion was sensitive to high concentrations of EGTA, suggesting that intracellular $\mathrm{Ca}^{2+}$ buffers play an important role in vesicle recruitment in both low- and high-frequency hair cells. In conclusion, our results indicate that microdomain coupling is important for exocytosis in high-frequency hair cells, suggesting a novel hypothesis for why these cells are more susceptible to sound-induced damage than low-frequency cells; high-frequency inner hair cells must have a low $\mathrm{Ca}^{2+}$ buffer capacity to sustain exocytosis, thus making them more prone to $\mathrm{Ca}^{2+}$-induced cytotoxicity.

Key words: calcium channels; cochlea; exocytosis; hair cells; ribbon synapse

Significance Statement

In the inner ear, sensory hair cells signal reception of sound. They do this by converting the sound-induced movement of their hair bundles present at the top of these cells, into an electrical current. This current depolarizes the hair cell and triggers the calciuminduced release of the neurotransmitter glutamate that activates the postsynaptic auditory fibers. The speed and precision of this process enables the brain to perceive the vital components of sound, such as frequency and intensity. We show that the coupling strength between calcium channels and the exocytosis calcium sensor at inner hair cell synapses changes along the mammalian cochlea such that the timing and/or intensity of sound is encoded with high precision.

\section{Introduction}

The sensory neuroepithelium of vertebrate auditory organs is tonotopically organized such that the characteristic frequency of

Received Sept. 3, 2016; revised Jan. 6, 2017; accepted Jan. 10, 2017.

Author contributions: H.v.G. and W.M. designed research; S.L.J., J.O., S.C., H.v.G., and W.M. performed research; S.L.J., J.O., S.C., H.v.G., and W.M. analyzed data; S.L.J., J.O., S.C., H.v.G., and W.M. wrote the paper.

This work was supported by Wellcome Trust 102892 to W.M. and National Institute of Deafness and Other Communication Disorders DC004274 to H.v.G. S.L.J. is a Royal Society University Research Fellow.

The authors declare no competing financial interests.

*S.L.J., J.O., and S.C. contributed equally to this work.

Correspondence should be addressed to either of the following: Dr. Walter Marcotti, Department of Biomedical Science, University of Sheffield, Sheffield S10 2TN, United Kingdom, E-mail: w.marcotti@sheffield.ac.uk; or Dr. Henrique von Gersdorff, Vollum Institute, Oregon Health and Science University, Portland, OR 97239. E-mail: vongersd@ohsu.edu. the hair cells (the sound frequency at which they respond best) gradually changes with their position along the sensory organ. Hair cells have developed unique morphological, molecular, and biophysical features that allow them to distinguish a wide range of sound frequencies and intensities (Fettiplace and Fuchs, 1999) while maintaining submillisecond temporal precision (Matthews and Fuchs, 2010; Heil and Peterson, 2017). However, the mechanisms by which hair cell ribbon synapses ensure accurate

This is an open-access article distributed under the terms of the Creative Commons Attribution License Creative Commons Attribution 4.0 International, which permits unrestricted use, distribution and reproduction in any medium provided that the original work is properly attributed. 
sound encoding are still largely unknown (Fuchs, 2005; Safieddine et al., 2012). Ribbons are able to tether a large number of vesicles at the cell's presynaptic active zones, allowing them to facilitate high rates of sustained neurotransmission (Glowatzki and Fuchs, 2002; Keen and Hudspeth, 2006). Vesicle fusion at hair cell synapses is triggered by $\mathrm{Ca}^{2+}$ entry through $\mathrm{Ca}_{\mathrm{V}} 1.3 \mathrm{Ca}^{2+}$ channels (Platzer et al., 2000), clustered at the cell's presynaptic active zones (Roberts et al., 1990; Coggins and Zenisek, 2009; Frank et al., 2010), and uses otoferlin as the major $\mathrm{Ca}^{2+}$ sensor for exocytosis (Roux et al., 2006). However, how $\mathrm{Ca}^{2+}$ is able to regulate exocytosis at mature ribbon synapses is still mostly undetermined.

Spatial tightening between $\mathrm{Ca}^{2+}$ channels and docked vesicles improves release efficiency and is important for fast and highfidelity neurotransmission, not only at functionally mature sensory synapses (e.g., calyx of Held) (Fedchyshyn and Wang, 2005; Leão and von Gersdorff, 2009; Chen et al., 2015), but also in the squid giant synapse (Augustine et al., 1991) and mammalian conventional synapses (Bucurenciu et al., 2008; Schmidt et al., 2013). Calcium nanodomain coupling between a few $\mathrm{Ca}^{2+}$ channels and the exocytotic $\mathrm{Ca}^{2+}$ sensor (Neher, 1998; Stanley, 2016) has also been proposed to control vesicle fusion in inner hair cells (IHCs) (Brandt et al., 2005; Wong et al., 2014). This tight coupling has the advantage of providing accurate temporal encoding for phase-locking to low-frequency tones (Rose et al., 1967; Li et al., 2014) and also allows for the synchronized release of multiple vesicles (Graydon et al., 2011), which produces large AMPAreceptor mediated EPSCs (Glowatzki and Fuchs, 2002). However, another hypothesis is that the coupling of $\mathrm{Ca}^{2+}$ influx and exocytosis is controlled by the cooperativity of many channels $\left(\mathrm{Ca}^{2+}\right.$ microdomain), and it is the $\mathrm{Ca}^{2+}$ sensor that generates the efficient exocytosis in mature IHC ribbon synapses (Johnson et al., 2010).

We have previously investigated the effect of the fast $\mathrm{Ca}^{2+}$ chelator BATPA on exocytosis and found it to be comparable in apical and basal gerbil IHCs (Johnson et al., 2008). However, BAPTA chelates $\mathrm{Ca}^{2+}$ independently from the tightness of the coupling between the $\mathrm{Ca}^{2+}$ source and the sensor for vesicle fusion (Wang and Augustine, 2015). Here we used instead the "slow" $\mathrm{Ca}^{2+}$ chelator EGTA, which has similar affinities for $\mathrm{Ca}^{2+}$ as BAPTA, but a 140-fold slower ON-binding rate (Naraghi and Neher, 1997), which allows it to bind $\mathrm{Ca}^{2+}$ slower than the sensor for exocytosis and, as such, act as a high-pass temporal filter for $\mathrm{Ca}^{2+}$ (Wang and Augustine, 2015). Therefore, we investigated the effect of varying the intracellular EGTA concentration in hair cells positioned at different locations along the mammalian cochlea (mouse and gerbil) and the amphibian papilla (bullfrog), thus covering cells tuned to sound frequencies from $\sim 300 \mathrm{~Hz}$ to $\sim 30 \mathrm{kHz}$. We found that the coupling between the $\mathrm{Ca}^{2+}$ channels and the exocytotic $\mathrm{Ca}^{2+}$ sensor at hair cell ribbon synapses changes with high-frequency cells being more microdomain, allowing them to better encode a large dynamic range of sound intensities, whereas low-frequency cells operate via $\mathrm{Ca}^{2+}$ nanodomains for precise time encoding. We also found that recovery from vesicle pool depletion was slowed by high EGTA concentrations. We propose that exocytosis at mature hair cell ribbon synapses can operate via either $\mathrm{Ca}^{2+}$ nanodomain or microdomain depending on their location along the sensory epithelium, the function of which could be to optimize the responses of these primary auditory receptors.

\section{Materials and Methods}

Electrophysiology from mammalian hair cells. IHCs from young adult gerbils of either sex (Müller, 1996) were studied in acutely dissected organs of Corti from postnatal day 18 (P18) to P60, where the day of birth is P0. Recordings were performed from IHCs positioned in the apical, middle, and basal gerbil cochlea of overlapping age range, which correspond to the in vivo mean characteristic frequency $(\mathrm{CF})$ of $\sim 0.35, \sim 2.5$, and $\sim 30$ $\mathrm{kHz}$, respectively. Experiments were also performed on P19 to P26 mouse (of either sex) IHCs positioned in the apical coil of the cochlea with a mean $\mathrm{CF}$ of $\sim 3.0 \mathrm{kHz}$. All experiments in mice and gerbils were performed in accordance with Home Office regulations under the Animals (Scientific Procedures Act) 1986 and following approval by the University of Sheffield Ethical Review Committee.

Cochleae were dissected from gerbils and mice in normal extracellular solution (in $\mathrm{mM}$ ) as follows: $135 \mathrm{NaCl}, 5.8 \mathrm{KCl}, 1.3 \mathrm{CaCl}_{2}, 0.9 \mathrm{MgCl}_{2}, 0.7$ $\mathrm{NaH}_{2} \mathrm{PO}_{4}, 5.6$ D-glucose, 10 HEPES-NaOH. Sodium pyruvate $(2 \mathrm{mM})$, amino acids, and vitamins were added from concentrates (Fisher Scientific). The $\mathrm{pH}$ was adjusted to 7.5 (osmolality $\sim 308 \mathrm{mmol} / \mathrm{kg}$ ). The dissected cochlear coils were transferred to a microscope chamber containing extracellular solution and viewed using an upright microscope (Olympus BX51WI or Nikon FN1) with Nomarski DIC optics and a long working distance $60 \times$ water-immersion objective.

Gerbil and mouse recordings were performed at body temperature $\left(34^{\circ} \mathrm{C}-37^{\circ} \mathrm{C}\right)$ using an Optopatch amplifier (Cairn Research). Patch pipettes $(2-3 \mathrm{M} \Omega$ ) were coated with surf-wax (Mr Zoggs SexWax) and contained the following (in $\mathrm{mM}$ ): 106 Cs-glutamate, $20 \mathrm{CsCl}, 3 \mathrm{MgCl}_{2}, 1$ EGTA-CsOH, $5 \mathrm{Na}_{2}$ ATP, $0.3 \mathrm{Na}_{2} \mathrm{GTP}, 5$ HEPES-CsOH, $10 \mathrm{Na}_{2}-$ phosphocreatine, $\mathrm{pH} 7.3(294 \mathrm{mmol} / \mathrm{kg})$. In the experiments in which 1 mM EGTA was replaced by different EGTA concentrations $(0.1,5$, and $10 \mathrm{mM}$ ), Cs-glutamate was adjusted to keep the osmolality constant. In a few experiments, perforated patch was used, and the pipette-filling solution contained the following (in $\mathrm{mM}$ ): $110 \mathrm{Cs}$-aspartate, $21 \mathrm{CsCl}, 3$ $\mathrm{MgCl}_{2}, 5 \mathrm{Na}_{2} \mathrm{ATP}, 1$ BAPTA, 5 HEPES-CsOH, $10 \mathrm{Na}_{2}$-phosphocreatine, $\mathrm{pH} 7.3$ (295 mmol/kg). The antibiotic amphotericin B (Merck Millipore) was dissolved in dry DMSO before dilution in the above intracellular solution to 120 or $240 \mu \mathrm{g} / \mathrm{ml}$ (Johnson et al., 2007).

Real-time changes in membrane capacitance $\left(\Delta C_{\mathrm{m}}\right)$ were measured as previously described (Johnson et al., 2008, 2010). Briefly, a $4 \mathrm{kHz}$ sine wave of $13 \mathrm{mV}$ RMS was applied to IHCs from $-81 \mathrm{mV}$ and was interrupted for the duration of the voltage step. The sine wave was small enough not to activate any significant membrane current because $\Delta C_{\mathrm{m}}$ requires a high and constant membrane resistance $\left(R_{\mathrm{m}}\right)$, which was $738 \pm 61 \mathrm{M} \Omega(n=87)$. In the experiments performed at the physiological membrane potentials (see Fig. 8), our single sine wave was sufficiently rapid to activate only a small amount of tonic $I_{\mathrm{Ca}}$, evident by the comparatively large $R_{\mathrm{m}}$ in these recordings ( $\left.639 \pm 77 \mathrm{M} \Omega, n=20\right)$, which could possibly lead to some facilitation of vesicle release (Cho et al., 2011). The capacitance signal from the Optopatch was filtered at $250 \mathrm{~Hz}$ and sampled at $5 \mathrm{kHz} . \Delta C_{\mathrm{m}}$ was measured by averaging the $C_{\mathrm{m}}$ trace over a $200 \mathrm{~ms}$ period following the voltage step and subtracting the prepulse baseline. Data were acquired using pClamp software (RRID: SCR_011323) and a Digidata 1440A (Molecular Devices) and analyzed with Origin 2016 (OriginLab, RRID:SCR_002815). Membrane potentials were corrected for the voltage drop across the series resistance (whole-cell recordings: apical coil IHCs, $4.8 \pm 0.1 \mathrm{M} \Omega, n=60$; middle, $4.9 \pm 0.2 \mathrm{M} \Omega, n=12$; basal, $5.5 \pm 0.2 \mathrm{M} \Omega, n=45$; perforated patch recordings: apical coil IHCs, $5.2 \pm 0.2 \mathrm{M} \Omega, n=4$; basal, $4.8 \pm 0.1 \mathrm{~m} \Omega$, $n=5$ ) and a liquid junction potential of $-11 \mathrm{mV}$, measured between electrode and bath solutions. The cell membrane capacitance $\left(C_{\mathrm{m}}\right)$ in whole cell was as follows: apical coil IHCs, $11.6 \pm 0.2 \mathrm{pF}, n=60$; middle, $11.3 \pm 0.5 \mathrm{pF}, n=12$; basal, $11.4 \pm 0.4 \mathrm{M} \Omega, n=45 ; C_{\mathrm{m}}$ in perforated patch was as follows: apical coil IHCs, $10.8 \pm 0.3 \mathrm{pF}, n=4$; basal, $10.0 \pm$ $0.5 \mathrm{M} \Omega, n=5$. The average voltage-clamp time constant (product of $R_{\mathrm{s}}$ and $C_{\mathrm{m}}$ ) in whole cell was $56 \pm 2 \mu \mathrm{s}$ in apical, $55 \pm 2 \mu \mathrm{s}$ in middle, and $62 \pm 4 \mu$ s in basal IHCs; in perforated patch, it was $55 \pm 2 \mu$ s in apical and $48 \pm 2 \mu \mathrm{s}$ in basal IHCs. Experiments were performed in the presence of $30 \mathrm{mM}$ TEA and $15 \mathrm{mM} 4$-AP in the extracellular solution (Fluka, Sigma-Aldrich) to block the BK current $\left(I_{\mathrm{K}, \mathrm{f}}\right.$ Kros et al., 1998) and de- 
layed rectifier $\mathrm{K}^{+}$currents $\left(I_{\mathrm{K}, \text { neo }}\right.$ and $\left.I_{\mathrm{K}, \mathrm{s}}\right)$, and linopirdine $(80 \mu \mathrm{M}$ : Tocris Bioscience) to block $I_{\mathrm{K}, \mathrm{n}}$ (Marcotti et al., 2003).

Statistical comparisons of means were made by the two-tailed $t$ test or, for multiple comparisons, ANOVA, one-way ANOVA followed by the Bonferroni test. Data are mean \pm SEM. $p<0.05$ indicates statistical significance.

Electrophysiology from bullfrog auditory hair cells. Following an Oregon Health and Science University (Institutional Animal Care and Use Committee) approved animal care protocol, amphibian papillae of adult female or male bullfrogs (Rana catesbeiana) were carefully dissected as previously described (Keen and Hudspeth, 2006; Li et al., 2009). Semi-intact preparations of hair cells and their connecting afferent fibers were placed in a recording chamber with artificial perilymph containing the following (in $\mathrm{mM}$ ): 95 $\mathrm{NaCl}, 2 \mathrm{KCl}, 2 \mathrm{CaCl}_{2}, 1 \mathrm{MgCl}_{2}, 25 \mathrm{NaHCO}_{3}, 3$ glucose, 1 creatine, $1 \mathrm{Na}-$ pyruvate, $\mathrm{pH}$ adjusted to 7.3 with $\mathrm{NaOH}$, and continuously bubbled with $95 \% \mathrm{O}_{2}$ and $5 \% \mathrm{CO}_{2}$ (osmolality $230 \mathrm{mmol} / \mathrm{kg}$ ). Oxygenated artificial perilymph was perfused continuously $(2-3 \mathrm{ml} / \mathrm{min})$ during the recordings, which were performed at room temperature.

An Olympus BX51WI microscope equipped with a $60 \times$ waterimmersion objective lens (Olympus) and digital CCD camera (QImaging Scientific) were used to view the preparation, and electrophysiological recordings were performed in the middle area of amphibian papillae at an average $\mathrm{CF}$ of $\sim 0.4 \mathrm{kHz}$ ( $\mathrm{Li}$ et al., 2014). All recordings were performed at room temperature using an EPC-10/2 patch-clamp amplifier and Patchmaster software (HEKA, RRID:SCR_000034). The control intracellular pipette solution contained the following (in $\mathrm{mM}$ ): 77 Csgluconate, $20 \mathrm{CsCl}, 1 \mathrm{MgCl}_{2}, 10$ TEA-Cl, 10 HEPES, 2 EGTA, $3 \mathrm{Mg}$-ATP, $1 \mathrm{Na}-\mathrm{GTP}$, and $5 \mathrm{Na}_{2}$-phosphocreatine (adjusted to $\mathrm{pH} 7.3$ with $\mathrm{CsOH}$ ). The amount of Cs-gluconate was adjusted to match osmolarity of 230 $\mathrm{mmol} / \mathrm{kg}$ for pipette solution containing 0.1 and $10 \mathrm{mM}$ EGTA instead of $2 \mathrm{mM}$ EGTA. For whole-cell recordings, patch pipettes of borosilicate glass were pulled to resistances of $6-7 \mathrm{M} \Omega$ for hair cells and $8-9 \mathrm{M} \Omega$ for afferent fibers. Hair cells were voltage-clamped with a resting membrane potential of either $-60 \mathrm{mV}$ or $-90 \mathrm{mV}$, and afferent fibers were held at $-90 \mathrm{mV}$ (Cho and von Gersdorff, 2014). Membrane potentials were corrected for a liquid junction potential of $10 \mathrm{mV}$. The current signal was low-pass filtered at $5.0 \mathrm{kHz}$ and sampled at $100 \mathrm{kHz}$. The averaged uncompensated series resistances in whole-cell recordings were $12.1 \pm 0.2$ $\mathrm{M} \Omega$ for hair cells $(n=93)$ and $26.5 \pm 1.7 \mathrm{M} \Omega$ for afferent fibers $(n=17)$. $\Delta C \mathrm{~m}$ measurements were performed under voltage clamp with the "Sine + DC" method (Lindau and Neher, 1988; Gillis, 2000) using an EPC-10/2 (HEKA) patch-clamp amplifier and Patchmaster software (HEKA). Under voltage-clamp conditions, $2 \mathrm{kHz}$ sine waves were superposed on the holding potential and the resulting current response was used to calculate $C_{\mathrm{m}}$ via a Patchmaster software emulator of a lock-in amplifier (Gillis, 2000).

Data analysis was performed with Igor Pro software (Wave Metrics, RRID:SCR_000325) and Prism (GraphPad Software, RRID: SCR_002798). Statistical significance was assessed with unpaired $t$ test and one-way ANOVA followed by the Bonferroni test. Data are expressed as mean \pm SEM.

\section{Results}

Whole-cell patch-clamp recordings were used to investigate $\mathrm{Ca}^{2+}$-dependent exocytosis in hair cells at specific CFs of the mature gerbil, mouse, and bullfrog auditory organs. Although the mouse and the frog are the most common animal models used for hearing research, they are mainly tuned to high- (mouse hearing frequency range: $\sim 2-100 \mathrm{kHz}$ ) (Ehret, 1975; Greenwood, 1990) and low- (bullfrog amphibian papilla: $\sim 0.15-1.2$ $\mathrm{kHz}$ ) (Lewis et al., 1982; Li et al., 2014) frequency, respectively. The advantage of the gerbil is that it has an extended lowfrequency hearing range $(\sim 0.1-60 \mathrm{kHz})$ (Müller, 1996), more similar to human hearing $(\sim 0.02-20 \mathrm{kHz})$ (Greenwood, 1990 ), which should demarcate better any tonotopic differences along the spiral extension of the cochlea in a single mammalian species.
To obtain physiologically relevant data, measurements were performed at body temperature (Johnson et al., 2005, 2010; Nouvian, 2007) and using the extracellular $\mathrm{Ca}^{2+}$ concentration present in the perilymph surrounding the IHCs (1.3 mM) (Wangemann and Schacht, 1996). The physiological coupling between $\mathrm{Ca}^{2+}$ influx and the synaptic machinery was investigated from experiments in which exocytosis was recorded in the presence of different intracellular concentrations of EGTA. This enables increases in intracellular $\mathrm{Ca}^{2+}$ to be buffered only relatively far away from its source and thus intercept $\mathrm{Ca}^{2+}$ traveling within a microdomain to the $\mathrm{Ca}^{2+}$ sensor for exocytosis (Neher, 1998; Stanley, 2016). This is different from the action of the $\mathrm{Ca}^{2+}$ chelator BAPTA, which binds $\mathrm{Ca}^{2+}$ more rapidly than the $\mathrm{Ca}^{2+}$ sensor for exocytosis and as such is able to chelate $\mathrm{Ca}^{2+}$ independently of the tightness of the coupling between the $\mathrm{Ca}^{2+}$ source and the exocytotic $\mathrm{Ca}^{2+}$ sensor (Wang and Augustine, 2015). As such, synaptic coupling can be inferred by the different effectiveness of EGTA and BAPTA in decoupling $\mathrm{Ca}^{2+}$ channels from the $\mathrm{Ca}^{2+}$ sensor for exocytosis. Physiological processes that are prevented by BAPTA but not by EGTA are mediated by a local or nanodomain coupling, whereas those that are blocked by both imply the presence of a longer distance between the $\mathrm{Ca}^{2+}$ source and its sensor (microdomain) (e.g., Adler et al., 1991, Borst and Sakmann, 1996; Meinrenken et al., 2002; Fedchyshyn and Wang, 2005; Wang and Augustine, 2015).

\section{Frequency-dependent variation in the coupling of $\mathrm{Ca}^{2+}$ influx and exocytosis}

Calcium-dependent exocytosis was measured from IHCs (P20P27) positioned in the apical (low-frequency: CF $\sim 0.35 \mathrm{kHz}$ ), middle ( $\mathrm{CF} \sim 2.5 \mathrm{kHz}$ ), and basal (high-frequency: $\mathrm{CF} \sim 30 \mathrm{kHz}$ ) regions of the gerbil cochlea. Calcium currents $\left(I_{\mathrm{Ca}}\right)$ and corresponding $\Delta C_{\mathrm{m}}$ recordings from IHCs positioned along the gerbil cochlea are shown in Figure 1. Recordings were obtained in response to $50 \mathrm{~ms}$ depolarizing voltage steps (holding potential of $-81 \mathrm{mV}$ ), which allows the release of only vesicles docked at the active zones, resembling the readily releasable pool (RRP), when performing experiments using physiological $1.3 \mathrm{mM}$ extracellular $\mathrm{Ca}^{2+}$ at body temperature (Fig. 2) (Johnson et al., 2005, 2010). The size of $I_{\mathrm{Ca}}$ was not significantly affected by the different concentrations of EGTA or by the position of the IHC along the cochlea (apical IHCs: $0.1 \mathrm{mM}$ EGTA, $-141 \pm 9 \mathrm{pA}, n=6 ; 10$ mM EGTA, $-176 \pm 18$ pA, $n=8$; middle IHCs: 0.1 mM EGTA, $-122 \pm 21 \mathrm{pA}, n=6 ; 10 \mathrm{mM} \mathrm{EGTA},-129 \pm 9 \mathrm{pA}, n=7$; basal IHCs: $0.1 \mathrm{mM}$ EGTA, $-136 \pm 10 \mathrm{pA}, n=13 ; 10 \mathrm{mM}$ EGTA, $-139 \pm 13 \mathrm{pA}, n=10)$. This is consistent with previous findings showing that the size of $I_{\mathrm{Ca}}$ in apical and basal gerbil IHCs was unaffected by different concentrations of the intracellular $\mathrm{Ca}^{2+}$ buffer BAPTA (Johnson et al., 2008, their Fig. 5). In $0.1 \mathrm{mM}$ EGTA, the peak $\Delta C_{\mathrm{m}}$ was found to be not significantly different in IHCs along the cochlea ( $p=0.09$, overall one-way ANOVA). Although in apical IHCs $10 \mathrm{mM}$ EGTA did not significantly affect $\Delta C_{\mathrm{m}}(9.6 \pm 1.0 \mathrm{fF}, n=8)$ compared with $0.1 \mathrm{mM} \mathrm{EGTA}(10.5 \pm$ $0.8 \mathrm{fF}, n=6, p=0.1$ ) (Fig. $1 A, D$ ), the ability of the $\mathrm{Ca}^{2+}$ chelator EGTA to uncouple $\mathrm{Ca}^{2+}$ influx and exocytosis greatly increased toward the high-frequency region of the gerbil cochlea. In the presence of $0.1 \mathrm{mM}$ intracellular EGTA, the size of the induced $\Delta C_{\mathrm{m}}$ in IHCs from the middle $(19.1 \pm 2.1 \mathrm{fF}, n=6$; Fig. $1 B, E)$ and basal $(22.7 \pm 3.9 \mathrm{fF}, n=13$; Fig. $1 C, F)$ cochlear regions were significantly larger $(p<0.005$ and $p<0.0001$, respectively) than the values obtained when EGTA was increased to $10 \mathrm{mM}$ (middle: $8.5 \pm 1.5 \mathrm{fF}, n=7$, Fig. $1 B, E$; basal: $1.3 \pm 0.9 \mathrm{fF}, n=10$, Fig. $1 C, F)$. In $10 \mathrm{mM}$ EGTA, $\Delta C_{\mathrm{m}}$ was significantly $(p<0.001)$ 
A

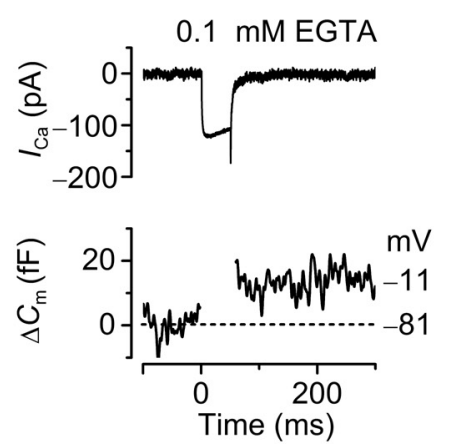

B
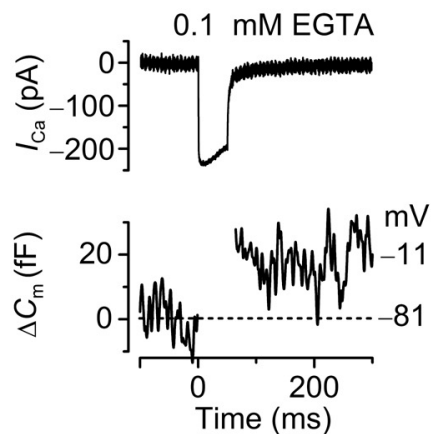

C
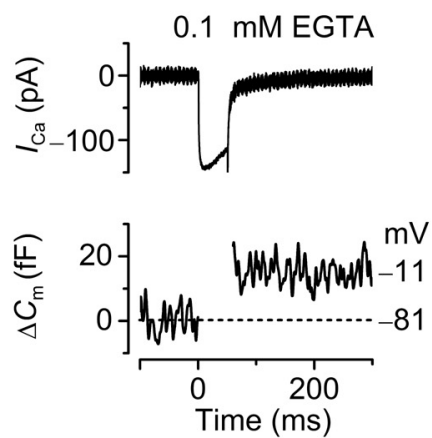

Gerbil IHC-Ac: $\sim 0.35 \mathrm{kHz}$
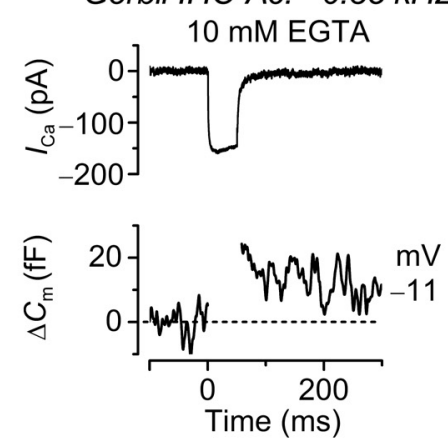

Gerbil IHC-Mc: $\sim 2.5 \mathrm{kHz}$
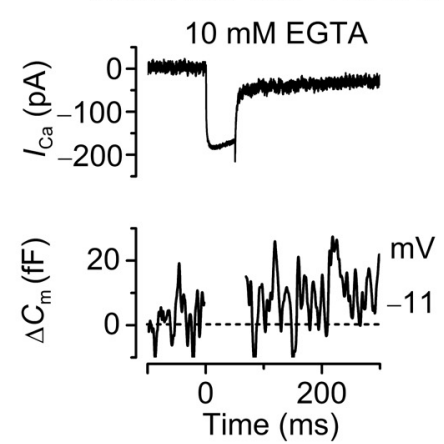

Gerbil IHC-Bc: $\sim 30 \mathrm{kHz}$
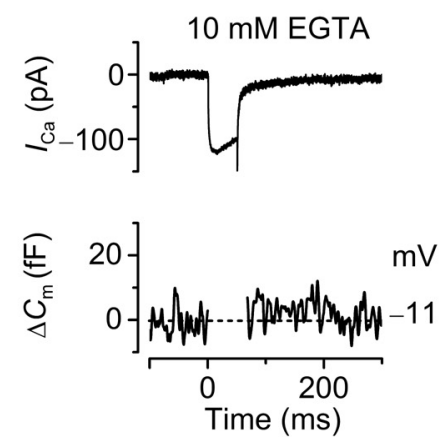

D

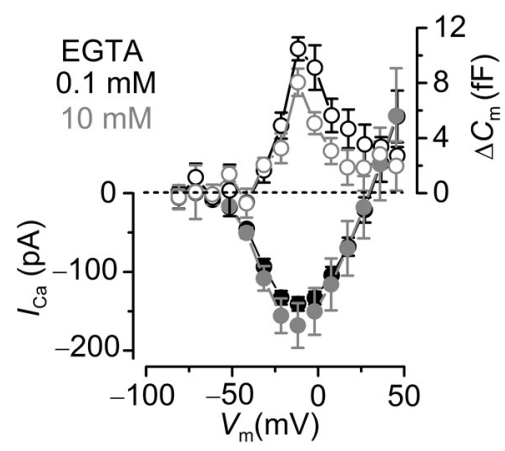

E

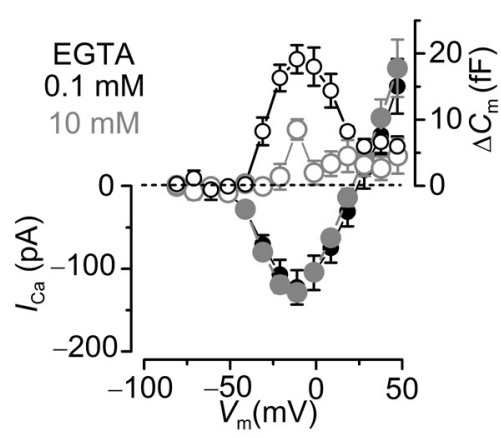

$\mathbf{F}$

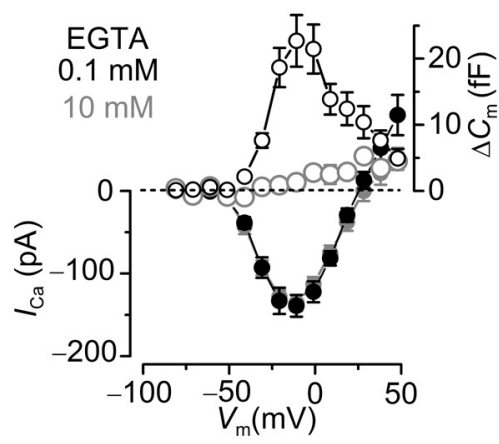

Figure 1. $\mathrm{Ca}^{2+}$ dependence of exocytosis in gerbil IHCs. $\boldsymbol{A}-\boldsymbol{C}, \mathrm{I}_{\mathrm{Ca}}$ and $\Delta \boldsymbol{C}_{\mathrm{m}}$ from apical $(\boldsymbol{A}: \sim 0.35 \mathrm{kHz})$, middle $(\boldsymbol{B}: \sim 2.5 \mathrm{kHz})$, and basal $(\boldsymbol{C}: \sim 30 \mathrm{kHz})$ IHCs in the presence of $0.1 \mathrm{mM}$ EGTA (left) and $10 \mathrm{mM}$ EGTA (right). Recordings were obtained in response to $50 \mathrm{~ms}$ voltage steps from the holding potential of $-81 \mathrm{mV}$ to $-11 \mathrm{mV}$. For clarity, only responses at $-81 \mathrm{mV}$ and $-11 \mathrm{mV}$ are

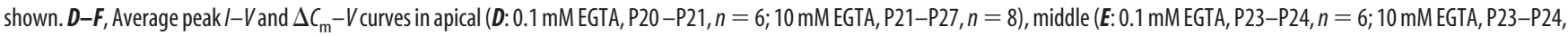
$n=7)$, and basal (F: $0.1 \mathrm{mM}$ EGTA, P18-P27, $n=13 ; 10 \mathrm{mM}$ EGTA, P21-P27, $n=10) \mathrm{IHCs}$. In this and the following figures, Ac, apical coil; Mc, middle coil; Bc, basal coil.

smaller in basal and middle IHCs compared with apical cells. With $10 \mathrm{mM}$ intracellular EGTA, the largely reduced or absent $\Delta C_{\mathrm{m}}$ in middle and basal IHCs, respectively, suggests the presence of a microdomain coupling between the $\mathrm{Ca}^{2+}$ channels and the $\mathrm{Ca}^{2+}$ sensor for vesicle fusion. This finding is also supported by the fact that, although the size of $\Delta C_{\mathrm{m}}$ in apical IHCs $(0.1 \mathrm{mM}$ EGTA: Fig. $1 D$ ) is comparable to that previously reported using 1 mM intracellular EGTA (50 ms voltage step) (Johnson et al., 2008), that measured in basal IHCs (Fig. $1 F$ ) was in most cells larger despite the similar number of synaptic ribbons per cell in the two regions (Johnson et al., 2009; Meyer et al., 2009). Because low-frequency IHCs seem to experience a nanodomain scenario, decreasing the concentration of EGTA from $1 \mathrm{mM}$ (Johnson et al., 2008) to $0.1 \mathrm{mM}$ (Fig. $1 D$ ) is unlikely to result in a different $\Delta C_{\mathrm{m}}$. However, the microdomain scenario in high-frequency IHCs would allow $\mathrm{Ca}^{2+}$ to travel further when reducing the concentration of EGTA from 1 to
$0.1 \mathrm{mM}$, and most likely able to recruit a small part of the secondary releasable pool in some IHCs (see below).

To investigate whether the vesicle pool dynamics in high EGTA also varied as a function of frequency position, we measured the rate of neurotransmitter release in gerbil IHCs (P18-P31) by measuring $\Delta C_{\mathrm{m}}$ in response to depolarizing voltage steps to $-11 \mathrm{mV}$ of varying duration ( $2 \mathrm{~ms}$ to $1.0 \mathrm{~s}$ : Fig. 2 ; interstep interval was at least $11 \mathrm{~s}$ ), which allowed us to investigate the emptying of different synaptic vesicle pool populations. When using $1 \mathrm{mM}$ intracellular EGTA and $1.3 \mathrm{mM}$ extracellular $\mathrm{Ca}^{2+}$, stimuli $\leq 50 \mathrm{~ms}$ reveal the RRP (see also Johnson et al., 2005, 2010). Longer steps induce the release of vesicles from a secondarily releasable pool (SRP) that is located further away from the $\mathrm{Ca}^{2+}$ channels (frog: Rutherford and Roberts, 2006; mouse: Moser and Beutner, 2000; gerbil: Johnson et al, 2008). In $10 \mathrm{mM}$ EGTA, the release from the SRP was almost completely abolished 
A

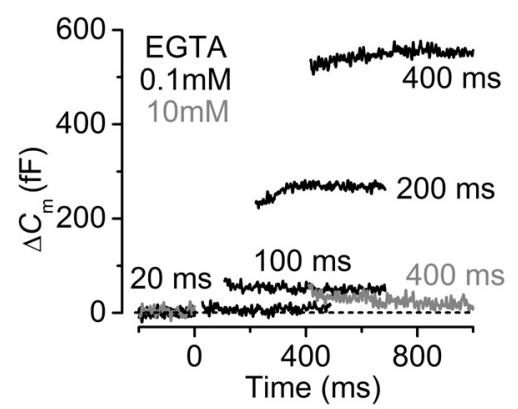

B

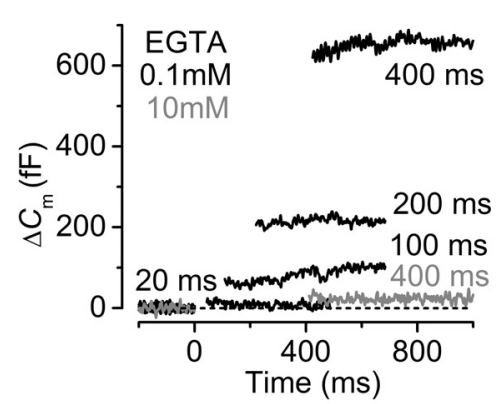

C

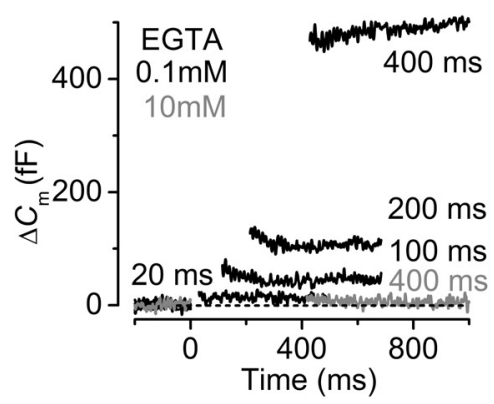

D

Gerbil IHC-Ac: $\sim 0.35 \mathrm{kHz}$

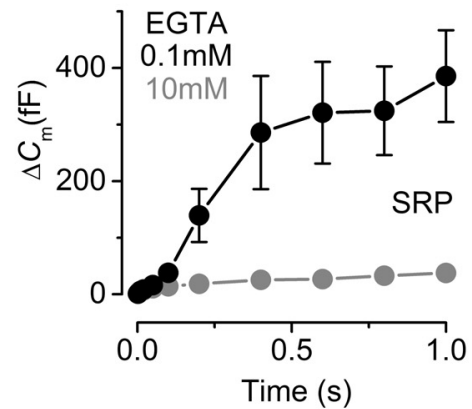

E

Gerbil IHC-Mc: $\sim 2.5 \mathrm{kHz}$

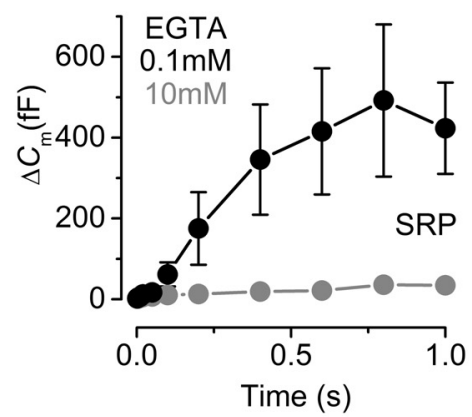

$\mathbf{F}$

Gerbil IHC-Bc: $\sim 30 \mathrm{kHz}$

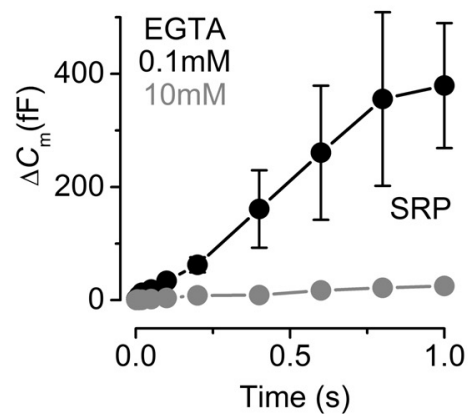

G

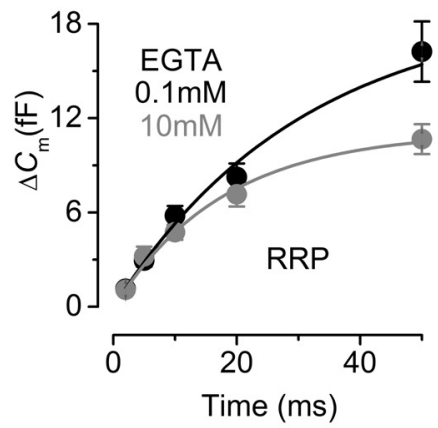

H

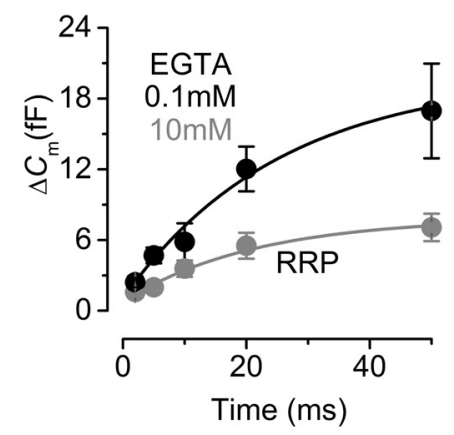

I

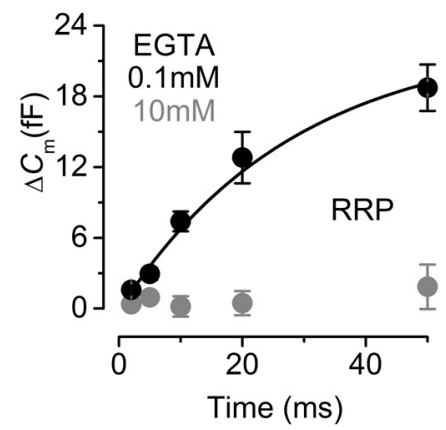

Figure 2. Kinetics of vesicle release in gerbil IHCS. $\boldsymbol{A}-\boldsymbol{C}, \Delta \boldsymbol{C}_{\mathrm{m}}$ from apical $(\boldsymbol{A})$, middle $(\boldsymbol{B})$, and basal (C) IHCs in the presence of $0.1 \mathrm{mM}$ EGTA (black traces) and $10 \mathrm{mM} \mathrm{EGTA}$ (gray traces). Recordings were obtained in response to voltage steps from $2 \mathrm{~ms}$ to $1.0 \mathrm{~s}$ (to $\sim-11 \mathrm{mV}$ ) that elicit both the RRP and SRP. For clarity, only a few responses are shown. $\boldsymbol{D}-\boldsymbol{F}, A$ Average $\Delta \boldsymbol{C}_{\mathrm{m}}$ obtained using the above protocol from apical ( $\boldsymbol{D}: 0.1 \mathrm{mM} \mathrm{EGTA}, n=8 ; 10 \mathrm{mM} \mathrm{EGTA}, n=5)$, middle (E: $0.1 \mathrm{mM} \mathrm{EGTA}, n=5 ; 10 \mathrm{mM} \mathrm{EGTA}, n=6)$, and basal ( $\boldsymbol{F}: 0.1 \mathrm{mM} \mathrm{EGTA,P18}-\mathrm{P} 20$, $n=6 ; 10 \mathrm{mM}$ EGTA, P21-P31, $n=11$ ) IHCs revealing the SRP. G-I, Isolated RRP (first 50 ms expanded from $\boldsymbol{D}-\boldsymbol{F}$ ) approximated with single exponential functions from the average data: apical (G: $0.1 \mathrm{mM} \mathrm{EGTA}$, maximum $\left.\Delta C_{\mathrm{m}}=19.2 \pm 5.0 \mathrm{fF}, \tau=31 \pm 12 \mathrm{~ms} ; 10 \mathrm{mM} \mathrm{EGTA}, \Delta C_{\mathrm{m}}=11.1 \pm 1.0 \mathrm{fF}, \tau=18 \pm 3 \mathrm{~ms}\right)$, middle $\left(\boldsymbol{H}: 0.1 \mathrm{mM} \mathrm{EGTA}, \Delta C_{\mathrm{m}}=19.9 \pm 5.8 \mathrm{fF}, \tau=\right.$ $\left.25 \pm 13 \mathrm{~ms} ; 10 \mathrm{mM} \mathrm{EGTA}, \Delta C_{\mathrm{m}}=7.9 \pm 1.3 \mathrm{fF}, \tau=21 \pm 8 \mathrm{~ms}\right)$, and basal $\left(I: 0.1 \mathrm{mM} \mathrm{EGTA}, \Delta C_{\mathrm{m}}=23.1 \pm 5.7 \mathrm{fF}, \tau=28 \pm 12 \mathrm{~ms} ; 10 \mathrm{mM}\right.$ EGTA data could not be fitted because $\Delta C_{\mathrm{m}}$ was almost absent). Note that the time on the $\mathrm{x}$-axis in $\boldsymbol{D}-\boldsymbol{H}$ indicates the voltage step duration.

in all IHCs investigated, regardless of their cochlear location (apical: Fig. $2 A, D$; middle: Fig. $2 B, E$; basal: Fig. $2 C, F)$, which is also in agreement with previous reports in mice (Moser and Beutner, 2000) and lower vertebrates (Graydon et al., 2011). However, the release from the RRP was differentially affected along the gerbil cochlea. In apical low-frequency IHCs $(\sim 0.35 \mathrm{kHz}$; Fig. $2 G)$, the size of the isolated RRP in $10 \mathrm{mM}$ EGTA $(11.7 \pm 1.2$ $\mathrm{fF}, n=5$ ) was not significantly different from that obtained in $0.1 \mathrm{mM}$ EGTA $(18.0 \pm 2.3 \mathrm{fF}, n=8, p=0.07$, from fits to individual IHCs), as also shown in Figure $1 D$. The initial release rate was also similar between the two recording conditions $(0.1 \mathrm{mM}$ EGTA: $817 \pm 115 \mathrm{fF} / \mathrm{s}$ or $22,074 \pm 3109$ vesicles/s, $n=8 ; 10 \mathrm{mM}$ EGTA: $596 \pm 129 \mathrm{fF} / \mathrm{s}$ or $16,115 \pm$
3493 vesicles/s, $n=5, p=0.2$, from fits to individual IHCs: Fig. 2G). However, compared with $0.1 \mathrm{mM}$ EGTA, $10 \mathrm{mM}$ EGTA largely reduced the release from the RRP in middle-coil IHCs (middle $\sim 2.5 \mathrm{kHz}: 0.1 \mathrm{mM}$ EGTA, $20.2 \pm 4.6 \mathrm{fF}, n=5$; $10 \mathrm{mM}$ EGTA, $7.1 \pm 1.1 \mathrm{fF}, n=6, p<0.02$; Fig. $2 H)$ and almost completely abolished it in basal cells (basal $\sim 30 \mathrm{kHz}$ : $0.1 \mathrm{mM}$ EGTA $22.1 \pm 1.4 \mathrm{fF}, n=6$; in $10 \mathrm{mM}$ EGTA, the RRP could only be measured in 2 of 11 IHCs and was $2.4 \pm 0.1 \mathrm{fF}$; Fig. 2I). As for IHCs in the apical coil, the initial release rate in middle IHCs was also similar between the two recording conditions $(0.1 \mathrm{mM}$ EGTA: $1000 \pm 101 \mathrm{fF} / \mathrm{s}$ or $27076 \pm 2754$ vesicles/s, $n=5 ; 10 \mathrm{mM}$ EGTA: $723 \pm 141 \mathrm{fF} / \mathrm{s}$ or $19558 \pm$ 3708 vesicles/s, $n=6, p=0.2$, from fits to individual IHCs). 
Using perforated-patch recordings that preserve the endogenous intracellular $\mathrm{Ca}^{2+}$ buffering, we found that the pool sizes and release kinetics of the RRP and SRP were comparable between apical and basal cells in these physiological conditions (Fig. $3 A-C$ ). We have previously shown that the endogenous buffer concentration was similar between low- and high-frequency gerbil IHCs when expressed as an equivalent BAPTA concentration (Johnson et al., 2008). However, when the $\Delta C_{\mathrm{m}}$ values obtained in perforated patch were extrapolated to those obtained using different concentrations of EGTA (Fig. 3D), they revealed a higher sensitivity to $\mathrm{Ca}^{2+}$ buffering in highfrequency IHCs $(\sim 2.9 \mathrm{mM})$ compared with low-frequency cells $(\sim 6.6 \mathrm{mM})$ (Fig. $3 D)$. However, this is not an indication of the endogenous buffer in IHCs but provides further evidence for a different exocytotic $\mathrm{Ca}^{2+}$ coupling of the RRP between apical and basal cells.

\section{Calcium channel and vesicle coupling in high-frequency mouse IHCs}

To confirm that the different coupling between $\mathrm{Ca}^{2+}$ influx and exocytosis observed in IHCs along the gerbil cochlea (Figs. 1-3) was due to the synaptic machinery being specialized to detect different frequencies, we performed experiments in the mouse and the bullfrog. Figure $4 A, B$ shows the maximal $I_{\mathrm{Ca}}$ and the corresponding $\Delta C_{\mathrm{m}}$ recorded from apical IHCs of the mouse cochlea $(\sim 3.0 \mathrm{kHz})$ in the presence of either low $(0.1$ and $1 \mathrm{mM}$ ) or high (5 and $10 \mathrm{mM}$ ) concentrations of intracellular EGTA, respectively. The apical coil of the mouse cochlea has a CF in the same range to that of the middle region of the gerbil cochlea $(\sim 2.5$ kHz: Figs. 1, 2). The data from 0.1 and 1 mM EGTA (Fig. 4) were pooled together because they produced overlapping results. Responses were obtained using $50 \mathrm{~ms}$ depolarizing voltage steps ( 10 $\mathrm{mV}$ nominal increments) from $-81 \mathrm{mV}$. The maximal size of $I_{\mathrm{Ca}}$ recorded in IHCs (P15-P26) was not significantly different between low (0.1 and $1 \mathrm{mM}:-179 \pm 21 \mathrm{pA}, n=5$; Fig. $4 C$ ) and high EGTA ( $5 \mathrm{mM}:-115 \pm 7 \mathrm{pA}, n=3$ or $10 \mathrm{mM}:-139 \pm 11 \mathrm{pA}, n=5$; Fig. $4 D$ ). However, the induced $\Delta C_{\mathrm{m}}$ was significantly reduced (overall: $p<0.002$, one-way ANOVA $)$ in the presence of $5 \mathrm{mM}(6.4 \pm 0.8 \mathrm{fF}$, $n=3, p<0.05$ post-test $)$ or $10 \mathrm{mM} \mathrm{EGTA}(2.0 \pm 1 \mathrm{fF}, n=5, p<$ 0.01 post-test) (Fig. $4 D$ ), compared with the lower concentrations (0.1 and 1 mM EGTA: $16 \pm 3 \mathrm{fF}, n=6$; Fig. $4 C$ ).

The rate of neurotransmitter release in mouse IHCs (P19-P26) was studied by measuring $\Delta C_{\mathrm{m}}$ in response to depolarizing voltage steps of increasing duration (Fig. $4 E$ ) as described for Figure 2. Voltage steps of up to $\sim 50 \mathrm{~ms}$ (RRP) produced an increase in $\Delta C_{\mathrm{m}}$ that could be approximated with a single exponential (Fig. $4 F$ ). However, in the presence of 5 or $10 \mathrm{mM}$ intracellular EGTA, the largely reduced size of the RRP was also associated with a significantly reduced initial release rate $(5 \mathrm{mM}$ : $374 \pm 33 \mathrm{fF} / \mathrm{s}$ or $10112 \pm 877$ vesicles $/ \mathrm{s}, n=4, p<0.05$ post-test; $10 \mathrm{mM} 203 \pm 36 \mathrm{fF} / \mathrm{s}$ or $5500 \pm$ 976 vesicles/s, $n=3, p<0.01$ post-test) compared with that measured in lower EGTA concentrations $(614 \pm 75 \mathrm{fF} / \mathrm{s}$ or $16589 \pm 2036$ vesicles/s, $n=5$ : average from fit to single cells; overall: $p<0.005$,
B

\section{Gerbil IHCs $=$ Ac: $\sim 0.35 \mathrm{kHz} ; \mathrm{Bc}: \sim 30 \mathrm{kHz}$}

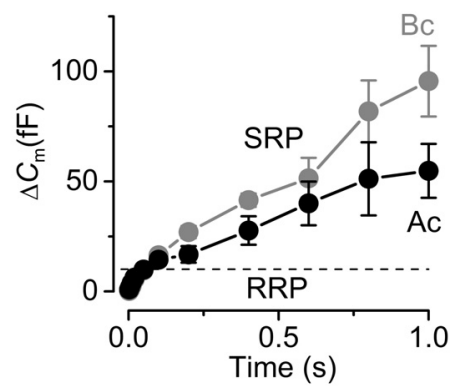

D

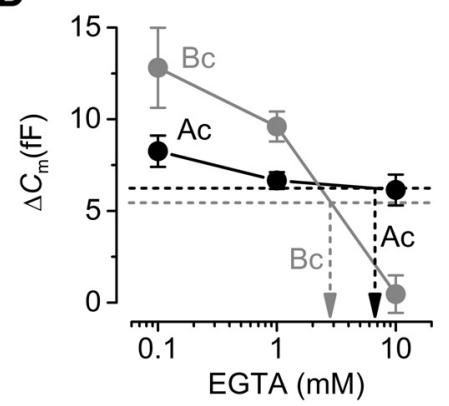

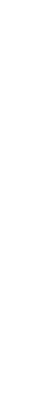

Figure 3. Kinetics of vesicle release in endogenous $\mathrm{Ca}^{2+}$ buffer from gerbil IHCs. $A, \Delta C_{\mathrm{m}}$ from apical (black) and basal (gray) HCs recorded with perforated patch. Recordings were obtained as described in Figure 2. For clarity, only a few responses are (first 50 ms expanded from $B$ ) approximated with single exponential functions from the single data (apical, maximum $\Delta C_{\mathrm{m}}=$ 11.6 $\pm 1.8 \mathrm{fF}, \tau=26 \pm 10 \mathrm{~ms}$; basal, $\Delta C_{\mathrm{m}}=12.2 \pm 3.2 \mathrm{fF}, \tau=31 \pm 17 \mathrm{~ms}$ ). $D$, The perforated-patch values of $\Delta C_{\mathrm{m}}$ at $20 \mathrm{~ms}$, trations (data from Fig. 2). The $1 \mathrm{mM}$ EGTA data are from Johnson et al. (2008). Note that the time on the $\mathrm{x}$-axis in $\boldsymbol{B}$ and $\boldsymbol{C}$ indicates

one-way ANOVA) (Fig. $4 F$ ). The SRP in high EGTA was almost absent (Fig. 4E). Considering that the total number of ribbons per IHC is 20 (Brandt et al., 2005; Meyer et al., 2009; Zampini et al., 2010 ), the vesicle release rate per ribbon was $\sim 829$ vesicles/s (low EGTA), 506 vesicles/s (5 mM EGTA), and 275 vesicles/s (10 mM EGTA) vesicles/s. This reduced exocytosis in mouse IHCs in the presence of high concentrations of EGTA has previously been reported in young (P12-P14) (Vincent et al., 2014) but not in more mature ( $>$ P14) (Moser and Beutner, 2000) cells using unphysiologically high extracellular $\mathrm{Ca}^{2+}(5-10 \mathrm{mM})$ and room temperature.

\section{Calcium channel and vesicle coupling in low-frequency tuned} bullfrog hair cells

We next investigated $I_{\mathrm{Ca}}$ and the corresponding $\Delta C_{\mathrm{m}}$ in single hair cells from a semi-intact adult bullfrog amphibian papilla preparation, which are tuned to a lower frequency range $(\sim 400-$ $500 \mathrm{~Hz}$ ) (Li et al., 2014), to examine the exocytotic $\mathrm{Ca}^{2+}$ coupling. To measure $I_{\mathrm{Ca}}$ and $\Delta C_{\mathrm{m}}$, we stimulated the hair cells with voltage-clamp step depolarizations from $-90 \mathrm{mV}$ to $-30 \mathrm{mV}$ for various durations (Fig. 5A). A depolarization to $-30 \mathrm{mV}$ elicits the peak $I_{\mathrm{Ca}}$ in bullfrog hair cells (Graydon et al., 2011). As the pulse duration increased, so did the resulting $\Delta C_{\mathrm{m}}$ (Fig. $5 A$ ) (Li et al., 2009). We compared $\Delta C_{\mathrm{m}}$ in response to depolarizing pulses with 0.1, 2 and $10 \mathrm{mM}$ intracellular EGTA (Fig. 5A,B). Depolarizing pulses $<50 \mathrm{~ms}$ did not show any significant difference in $\Delta C_{\mathrm{m}}$ between 2 and $10 \mathrm{mM}$ EGTA (Fig. $5 B$; unpaired $t$ test, $p<$ 0.05 ) (Graydon et al., 2011). However, $\Delta C_{\mathrm{m}}$ was significantly larger for $50 \mathrm{~ms}$ pulses (Fig. $5 B$ ). Our previous study shows that a pulse $<50 \mathrm{~ms}$ from $-90 \mathrm{mV}$ to $-30 \mathrm{mV}$ only triggers the RRP of 
A
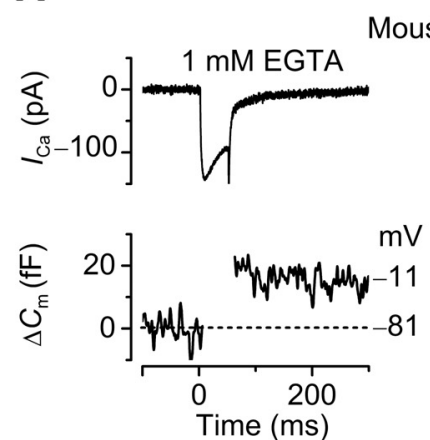

C

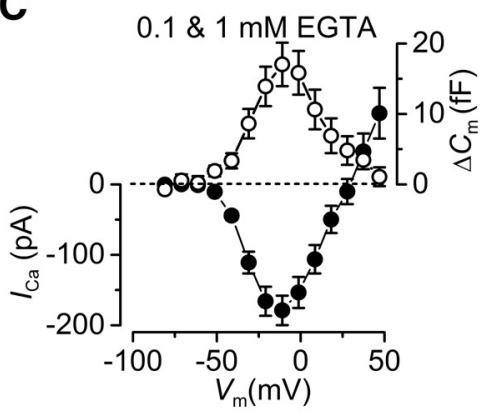

E

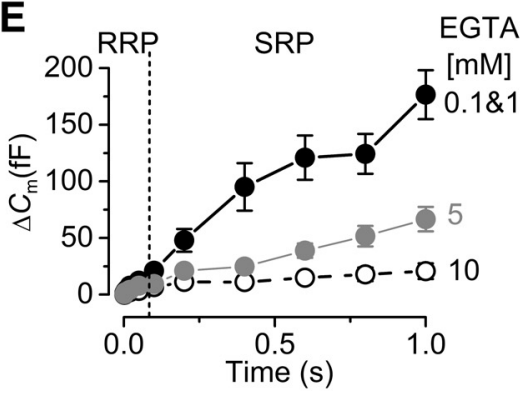

B

Mouse IHC $\sim 3 \mathrm{kHz}$
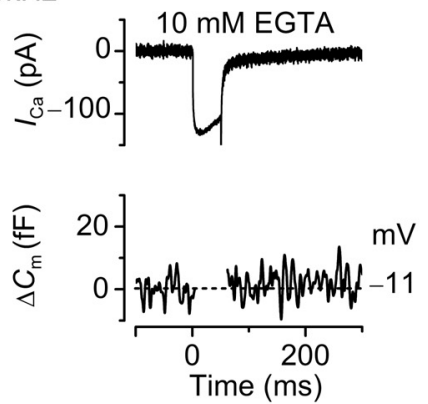

D

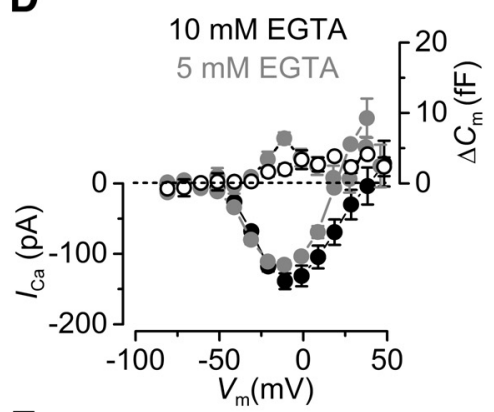

$\mathbf{F}$

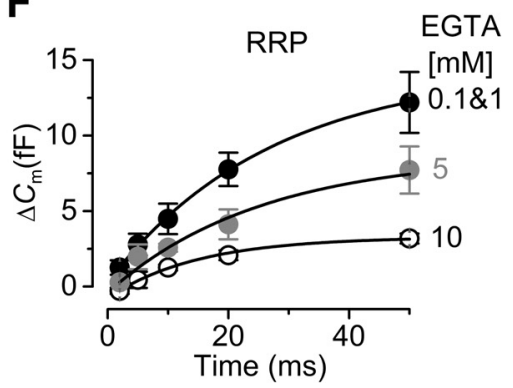

Figure 4. $\quad \mathrm{Ca}^{2+}$ currents and $\Delta C_{\mathrm{m}}$ in mouse IHCs. $A, B, I_{\mathrm{Ca}}$ (top panels) and $\Delta C_{\mathrm{m}}$ (bottom panels) responses recorded from IHCs positioned in the apical region $(C F: \sim 3.0 \mathrm{kHz})$ of the mouse cochlea in the presence of low $(0.1$ and $1 \mathrm{mM})$ and high $(10 \mathrm{mM})$ concentrations of intracellular EGTA, respectively. Recordings were obtained in response to $50 \mathrm{~ms}$ voltage steps from the holding potential of $-81 \mathrm{mV}$ to $-11 \mathrm{mV}$. C, D, Average peak current (I, bottom) and capacitance $\left(\Delta C_{\mathrm{m}}\right.$, top) plotted as a function of membrane potential from IHCs recorded in the presence of low and high intracellular EGTA, respectively. $\boldsymbol{E}$, Average $\Delta C_{\mathrm{m}}$ in response to voltage steps from $2 \mathrm{~ms}$ to $1.0 \mathrm{~s}$ (to $\sim-11 \mathrm{mV}$ ) showing the RRP and SRP. $\boldsymbol{F}, \mathrm{RRP}$ (first $50 \mathrm{~ms}$ expanded from $\boldsymbol{E}$ ) approximated with single exponential functions for the different concentrations of EGTA used ( 0.1 and $1 \mathrm{mM}$ : maximum $\Delta C_{\mathrm{m}}=$ $\left.16.4 \pm 3.4 \mathrm{fF}, \tau=32 \pm 10 \mathrm{~ms} ; 5 \mathrm{mM}: \Delta C_{\mathrm{m}}=8.2 \pm 2.0 \mathrm{fF}, \tau=21 \pm 4 \mathrm{~ms} ; 10 \mathrm{mM}: \Delta C_{\mathrm{m}}=3.4 \pm 0.4 \mathrm{fF}, \tau=17 \pm 2 \mathrm{~ms}\right)$.

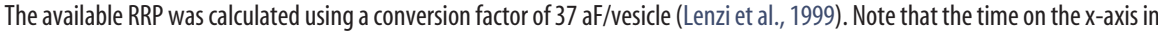
$\boldsymbol{E}$ and $\boldsymbol{F}$ indicates the voltage step duration.

hair cells, which includes $\sim 700$ vesicles per hair cell, or 12 vesicles per synaptic ribbon (Graydon et al., 2011). To confirm this insensitivity of the RRP to EGTA, we compared $\Delta C_{\mathrm{m}}$ in response to pulses of 20 and $500 \mathrm{~ms}$ with $0.1,2$, and $10 \mathrm{mM}$ intracellular EGTA (Fig. $5 C, D$ ). The average $\Delta C_{\mathrm{m}}$ in response to a $20 \mathrm{~ms}$ pulse was not significantly different with $0.1 \mathrm{mM}(21.7 \pm 1.7 \mathrm{fF}, n=$ 21), $2 \mathrm{mM}(17.8 \pm 1.4 \mathrm{fF}, n=18)$, and $10 \mathrm{mM}$ EGTA (17.4 \pm $1.0 \mathrm{fF}, n=14$, one-way ANOVA; Fig. 5C). In contrast, different concentrations of intracellular EGTA significantly changed the average $\Delta C_{\mathrm{m}}$ in response to a $500 \mathrm{~ms}$ pulse (overall: $p<0.006$, one-way ANOVA; Fig. $5 D): \Delta C_{\mathrm{m}}$ with $0.1 \mathrm{mM}(203.8 \pm 34.8 \mathrm{fF}$, $n=16$ ), which was significantly different from that with $10 \mathrm{mM}$ EGTA (104.1 $\pm 8.5 \mathrm{fF}, n=13, p<0.05$, post-test; Fig. $5 A$ ), although the $\Delta C_{\mathrm{m}}$ with $2 \mathrm{mM}(147.3 \pm 9.1 \mathrm{fF}, n=34)$ was not significantly different from those with 0.1 and $10 \mathrm{mM}$ EGTA (post-test). In summary, our data suggest that, in stark contrast to mouse high-frequency IHCs (Fig. 4), the release of vesicles in the RRP from lowfrequency hair cells is relatively insensitive to the concentration of intracellular EGTA. However, for longer depolarizing pulses of 50 and $500 \mathrm{~ms}$, we do find that release is significantly reduced by $10 \mathrm{mM}$ EGTA. This suggests that, during a longer depolarizing pulse, the recruitment of vesicles from a reserve pool is sensitive to global rises in intracellular free $\mathrm{Ca}^{2+}$ and is thus sensitive to the intracellular levels of EGTA. The RRP of amphibian papilla hair cells, which are tuned to lowfrequency sound signals, is thus controlled by nanodomain $\mathrm{Ca}^{2+}$ coupling.

\section{Paired-pulse responses in gerbil IHCs and bullfrog auditory hair cells}

We investigated possible differences in the rate of $\Delta C_{\mathrm{m}}$ recovery from gerbil IHCs (P18-P27) positioned in the apical and basal cochlear regions by applying a twopulse protocol in which cells were depolarized to $-11 \mathrm{mV}$ for $50 \mathrm{~ms}$, which recruited the RRP, while changing the interpulse interval (IPI) from $10 \mathrm{~ms}$ up to $1.0 \mathrm{~s}$ (Fig. 6A). Examples of $\Delta C_{\mathrm{m}}$ recorded from apical and basal IHCs using the twopulse protocol and in the presence of either $0.1 \mathrm{mM}$ EGTA or $10 \mathrm{mM}$ EGTA are shown in Figure $6 B$ and $C$, respectively. The average $\Delta C_{\mathrm{m}}$ ratio $\left(\Delta C_{\mathrm{m}}{ }^{2} / \Delta C_{\mathrm{m}}{ }^{1}\right.$ : Fig. $6 A)$ from apical IHCs (0.1 mM EGTA, $n=12 ; 10 \mathrm{mM} \mathrm{EGTA,} n=6)$ was plotted against IPI, and the data were well approximated with a single exponential function (Fig. 6D). For basal IHCs, the average $\Delta C_{\mathrm{m}}$ ratio in $0.1 \mathrm{mM}$ EGTA showed an initial depression at short intervals and then facilitation at $\sim 100 \mathrm{~ms}$ (Fig. $6 E$ ) (Goutman and Glowatzki, 2011; Cho et al., 2011).

To study whether the concentration of EGTA can affect short-term plasticity at low-frequency tuned hair cell synapses (tuned to $\sim 400-500 \mathrm{~Hz}$ ), we performed paired recordings between adult bullfrog hair cells and their afferent fibers. We held presynaptic hair cells at $-60 \mathrm{mV}$, which is close to their physiological in vivo resting membrane potential (Crawford and Fettiplace, 1980; Pitchford and Ashmore, 1987) and measured paired-pulse ratios (PPRs) of EPSCs using 2 and 10 $\mathrm{mM}$ intracellular EGTA in the patch pipette of the hair cell (Fig. $7 A$ ). Hair cells were stimulated by a pair of $20 \mathrm{~ms}$ depolarizing pulses from $-60 \mathrm{mV}$ to $-30 \mathrm{mV}$ with various IPIs and EPSCs recorded from the connected postsynaptic afferent fibers (Fig. $7 A, B)$. The average amplitude of the first EPSC was not significantly different with $2 \mathrm{mM}(2504 \pm 307 \mathrm{pA}, n=20)$ and $10 \mathrm{mM}$ EGTA $(2582 \pm 499 \mathrm{pA}, n=18, p=0.89$, unpaired $t$ test $)$, showing that the RRP exocytosis released by $20 \mathrm{~ms}$ pulses is insensitive to the concentration of EGTA. These results using AMPA receptor-mediated EPSCs confirm our earlier results with $\Delta C_{\mathrm{m}}$ changes in hair cells held at $-90 \mathrm{mV}$ (see Fig. 5A,C). 

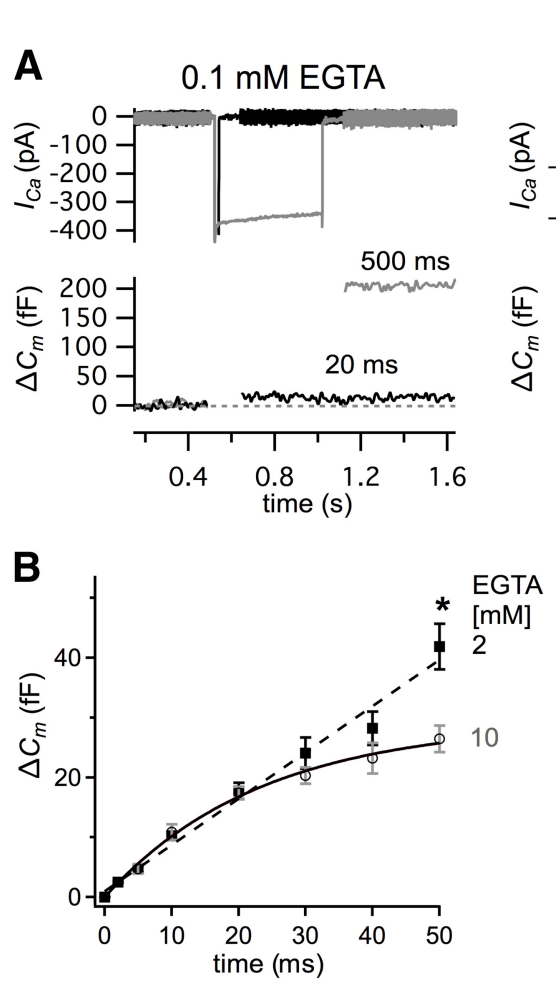
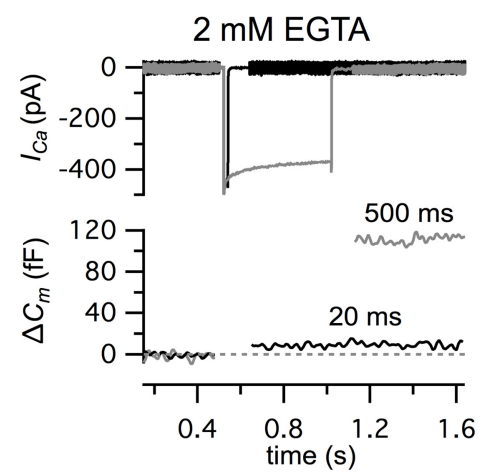

C

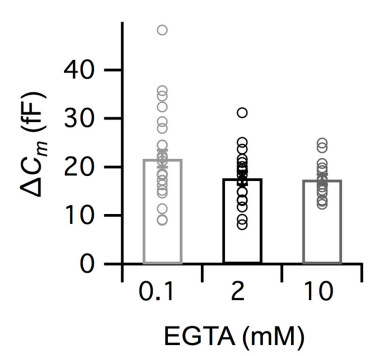

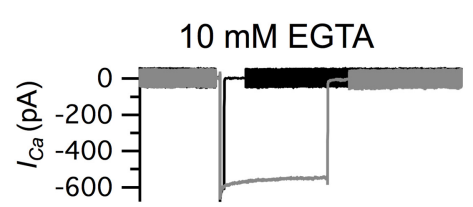

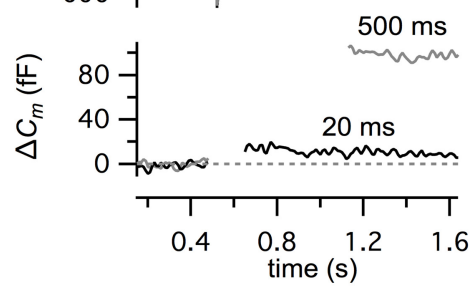

D

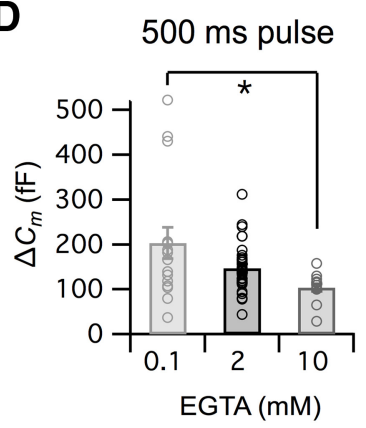

Figure 5. $\mathrm{Ca}^{2+}$ currents and $\Delta C_{\mathrm{m}}$ in bullfrog hair cells tuned to $\sim 400-500 \mathrm{~Hz}$ sound signals. $A$, Calcium current $\left(I_{\mathrm{Ca}_{\mathrm{a}}}\right)$ and membrane capacitance $\left(\boldsymbol{C}_{\mathrm{m}}\right)$ were measured while hair cells were depolarized from a holding potential of $-90 \mathrm{mV}$ to $-30 \mathrm{mV}$ for $20 \mathrm{~ms}$ (black) and $500 \mathrm{~ms}$ (gray) with $0.1 \mathrm{mM}$ (left), $2 \mathrm{mM}$ (middle), and $10 \mathrm{mM}$ of intracellular EGTA (right). Note the change in vertical scales for the $C_{\mathrm{m}}$ data and the large $\Delta C_{\mathrm{m}}$ jump (exocytosis) produced by $500 \mathrm{~ms}$ depolarizing pulses when $0.1 \mathrm{mM}$ EGTA is used in the patch pipette internal solution. $B$, Average $\Delta C_{\mathrm{m}}$ in response to voltage steps from 2 to $50 \mathrm{~ms}$ with $2 \mathrm{mM}$ (black) and $10 \mathrm{mM} \mathrm{EGTA}$ (gray). The depolarization of $50 \mathrm{~ms}$ from $-90 \mathrm{mV}$ to $-30 \mathrm{mV}$ only showed significant difference of $\Delta C_{\mathrm{m}}$ between 2 and $10 \mathrm{mMEGTA} .{ }^{*} p<0.05$ (unpaired $t$ test). Data modified with permission from Graydon et al. (2011). C, Comparison of $\Delta C_{\mathrm{m}}$ in response to voltage steps of $20 \mathrm{~ms}$ from $-90 \mathrm{mV}$ to $-30 \mathrm{mV}$ using $0.1 \mathrm{mM}$ (light gray, $n=27,21.7 \pm 1.7 \mathrm{fF}$ ), $2 \mathrm{mM}$ (black, $n=18,17.8 \pm 1.4 \mathrm{fF}$ ), and $10 \mathrm{mM}$ (gray, $n=14,17.4 \pm 1.0 \mathrm{fF}$ ) ofEGTA. One-way ANOVA did not show significant difference ( $p=0.098$ ). $D$, Comparison of $\Delta C_{\mathrm{m}}$ in response to voltage steps of $500 \mathrm{~ms}$ pulse from $-90 \mathrm{mV}$ to $-30 \mathrm{mV}$ using $0.1 \mathrm{mM}$ (light gray, $n=16,203.8 \pm 34.8 \mathrm{fF}$ ), $2 \mathrm{mM}$ (black, $n=34,147.3 \pm 9.1 \mathrm{fF}$ ), and 10 $\mathrm{mM}$ (gray, $n=13,104.1 \pm 8.5 \mathrm{fF}$ ) of EGTA. The $\Delta C_{\mathrm{m}}$ jumps in panels $\boldsymbol{C}$ and $\boldsymbol{D}$ were measured after 4 min from whole-cell break-in to allow for the full diffusion of EGTA into the hair cell. 0 ne-way ANOVA followed the Bonferroni test showed significant difference (overall: $p=0.006$ ).

We next studied the changes in PPR with 2 and 10 mM EGTA. While hair cells were held at $-60 \mathrm{mV}$, the second EPSC was smaller than the first EPSC throughout various IPIs (from 3 $\mathrm{ms}$ to $4 \mathrm{~s}$ ), showing a robust paired-pulse depression (Fig. $7 A, B)$. For short IPIs, such as $20 \mathrm{~ms}$, this synapse shows very strong paired-pulse depression; and as the IPIs get longer, paired-pulse depression recovers (Fig. 7A,B). This depression is not caused by AMPA receptor desensitization (Graydon et al., 2014), and more likely reflects vesicle pool depletion (Cho et al., 2011). We examined whether the enhanced level of EGTA can affect the recovery from paired-pulse depression. With $2 \mathrm{mM}$ intracellular EGTA, a double exponential function could fit the recovery of PPR with fast $\left(\tau_{1}=15 \mathrm{~ms} ; 63 \%\right)$ and slow $\left(\tau_{2}=602 \mathrm{~ms} ; 37 \%\right)$ time constants (Fig. 7C) (Cho et al., 2011). When we increased the concentration of intracellular EGTA to $10 \mathrm{mM}$, recovery of paired-pulse depression was delayed for both the fast $\left(\tau_{1}=92 \mathrm{~ms} ; 35 \%\right)$ and slow $\left(\tau_{2}=\right.$ $1161 \mathrm{~ms} ; 65 \%$ ) time constants. The median (weighted-mean) time constant increased significantly from $232 \mathrm{~ms}$ with $2 \mathrm{mM}$ EGTA to $787 \mathrm{~ms}$ with $10 \mathrm{mM}$ EGTA. These data thus indicate that recovery of paired-pulse depression is dependent on global intracellular $\mathrm{Ca}^{2+}$ levels within hair cells. This suggests again that the recruitment of vesicles from a reserve vesicle pool to the RRP is sensitive to the intracellular levels of EGTA and thus to the intracellular free $\mathrm{Ca}^{2+}$.
Exocytosis under physiological resting membrane potential in gerbil IHCs

The above experiments in mice and gerbils were performed using a holding potential of $-81 \mathrm{mV}$, which is commonly used for exocytosis (capacitance measurements) studies from hair cell ribbon synapses (mouse: Moser and Beutner, 2000; Johnson et al., 2010; Wong et al., 2014; gerbil: Johnson et al., 2009; bullfrog: Li et al., 2009; Cho et al., 2011). Because the estimated in vivo resting potential is likely to be $\sim-50 \mathrm{mV}$ for apical and $-60 \mathrm{mV}$ for basal IHCs (Johnson et al., 2011; Johnson, 2015), and $I_{\mathrm{Ca}}$ has been shown to activate at $\sim-60 \mathrm{mV}$ (gerbils) (Johnson and Marcotti, 2008), cells will be subjected to some continuous $\mathrm{Ca}^{2+}$ influx even at rest (see Materials and Methods). Therefore, we investigated gerbil IHC (P19-P28) exocytosis and the coupling between $\mathrm{Ca}^{2+}$ influx and the RRP using the more physiological resting membrane potentials (Fig. 8). For these experiments, $1 \mathrm{mM}$ EGTA was used as the intracellular $\mathrm{Ca}^{2+}$ buffer in apical and basal IHCs because it produces comparable $\Delta C_{\mathrm{m}}$ (Johnson et al., 2008 ) as those measured in perforated patch recordings (Fig. $8 E$ ) for both the RRP and SRP. This also allowed us to test the specific effect of the theoretical in vivo membrane potential on the release and replenishment of the RRP. Despite the different resting membrane potentials, the maximal $I_{\mathrm{Ca}}$ (apical: $-128 \pm 13 \mathrm{pA}$, $n=7$; basal: $-125 \pm 11 \mathrm{pA}, n=9)$ and the corresponding $\Delta C_{\mathrm{m}}$ (apical: $10.5 \pm 1.1 \mathrm{fF}$; basal: $8.8 \pm 1.4 \mathrm{fF}$ ) was similar between 
A

B
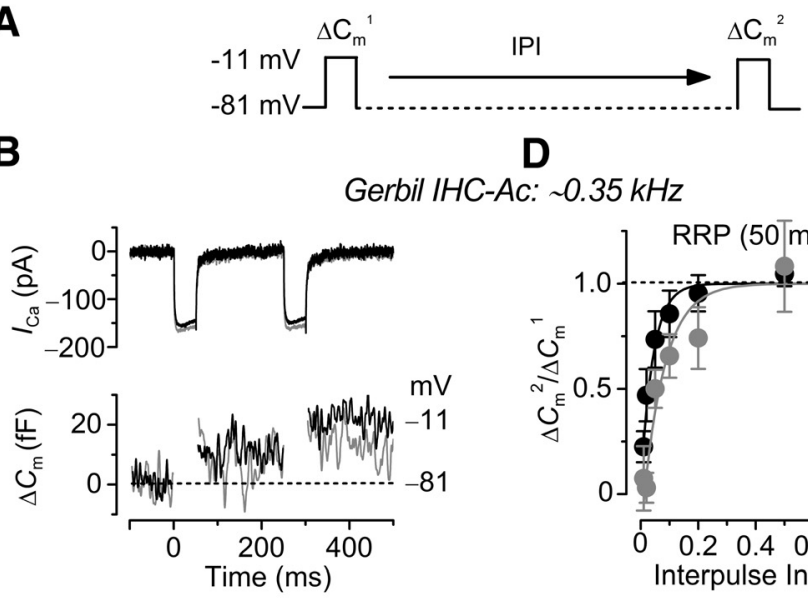

C

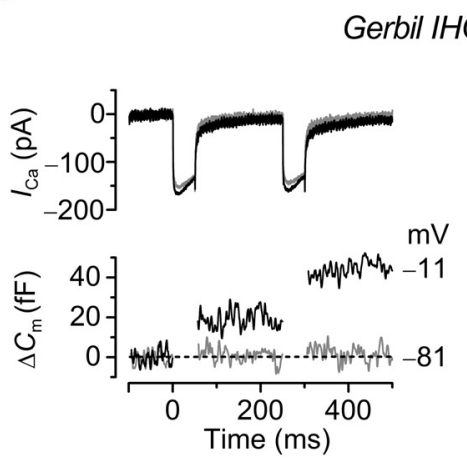

$E$

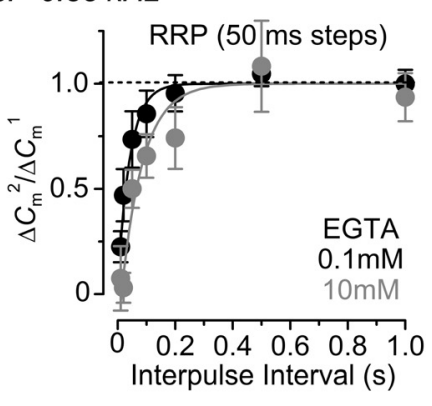

: $30 \mathrm{kHz}$

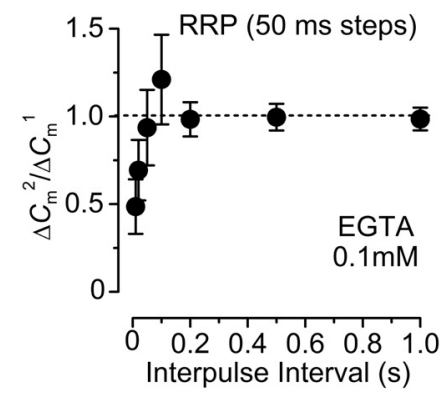

Figure 6. Rate of $\Delta C_{\mathrm{m}}$ recovery in gerbil IHCS. $A$, Schematic diagram of the paired-pulse protocol used to stimulate IHCs. $\Delta C_{\mathrm{m}}$ was elicited in response to $50 \mathrm{~ms}$ depolarizing voltage steps to $-11 \mathrm{mV}$ (holding potential of $-81 \mathrm{mV}$ ) at time 0 and varying the $\operatorname{IPI}(10,20,40,100,200$, and $500 \mathrm{~ms}, 1 \mathrm{~s})$ after the initial step. $\boldsymbol{B}, \boldsymbol{C}, I_{\mathrm{Ca}}$ and $\Delta \boldsymbol{C}_{\mathrm{m}}$ from apical $(\boldsymbol{B}: \sim 0.35 \mathrm{kHz})$ and basal $(\boldsymbol{C}: \sim 30 \mathrm{kHz})$ IHCs in the presence of $0.1 \mathrm{mM}$ EGTA (black) and $10 \mathrm{mMEGTA}$ (gray). $\boldsymbol{D}, \boldsymbol{E}$, Average $\Delta C_{\mathrm{m}}$ ratio $\left(\Delta C_{\mathrm{m}}{ }^{2} / \Delta C_{\mathrm{m}}{ }^{1} ; A\right)$ from apical (D) and basal $(\boldsymbol{E})$ IHCS. $\boldsymbol{D}$, In apical IHCS, the data were plotted against IPI and fitted with a single exponential function $\left(0.1 \mathrm{mM} \mathrm{EGTA}, \tau_{1}=\right.$ $42.1 \pm 8.1 \mathrm{~ms}, n=12 ; 10 \mathrm{mM} \mathrm{EGTA}, \tau_{1}=75.1 \pm 17.1 \mathrm{~ms}, n=6$; significantly different at $\left.p<0.0005\right)$. Basal IH(s showed an initial facilitation followed by a decline $(\boldsymbol{E})$. $\boldsymbol{E}$, The data from $10 \mathrm{mM}$ EGTA were omitted because $\Delta \boldsymbol{C}_{\mathrm{m}}$ was almost absent (see $\boldsymbol{C}$ ), which made it difficult to measure the $\Delta C_{\mathrm{m}}{ }^{2} / \Delta C_{\mathrm{m}}{ }^{1}$ ratio with accuracy.

apical and basal IHCs (Fig. $8 A-D$ ), as well as the size of the RRP (Fig. $8 E$ ). However, the rate of $\Delta C_{\mathrm{m}}$ recovery during paired pulses was significantly faster in basal $(\tau=27 \pm 11 \mathrm{~ms}, n=6$, from fits to single IHCs, $p<0.02)$ than in apical IHCs $(\tau=156 \pm 43 \mathrm{~ms}$, $n=5$ ). This is in line with our findings in the bullfrog showing that faster recovery depends on the availability of global free intracellular $\mathrm{Ca}^{2+}$ present in a microdomain situation (Fig. $7 C$ ).

\section{Discussion}

Using physiological recording conditions, in terms of extracellular $\mathrm{Ca}^{2+}$ level and body temperature, we show that the coupling between $\mathrm{Ca}^{2+}$ channels and the $\mathrm{Ca}^{2+}$ sensor for vesicle fusion changes as a function of the cell's frequency position. While lowfrequency hair cells $(\sim<2 \mathrm{kHz})$, which phase-lock to sound, exhibit a nanodomain coupling between $\mathrm{Ca}^{2+}$ channels and $\mathrm{Ca}^{2+}$ sensor, high-frequency cells have a looser coupling, which becomes progressively more microdomain along the gerbil cochlea. We have also shown that the level of intracellular $\mathrm{Ca}^{2+}$ buffer affects the speed of recovery from paired-pulse synaptic depression. We propose that either nanodomain or microdomain coupling is present in mature auditory hair cells, the function of which is to preserve the precise temporal coding of sound in phase-locked low-frequency hair cells and stimulus intensity in high-frequency cells, respectively.

\section{Mechanisms of $\mathrm{Ca}^{2+}$ influx-secretion coupling in IHCs}

A characteristic feature of the coupling between $\mathrm{Ca}^{2+}$ entry and vesicle fusion at IHC ribbon synapses is the change in the $\mathrm{Ca}^{2+}$ dependence of exocytosis from a high-order relation in immature cells to linear in mature post-hearing cells (Brandt et al., 2005; Johnson et al., 2005, 2008, 2010; Wong et al., 2014). However, such linearization in synaptic function only occurs in mature high-frequency IHCs responding to sound frequencies above a few $\mathrm{kHz}$ (Johnson et al., 2008, 2009), which encompasses the entire frequency range in the mouse cochlea $(\sim 3-$ $100 \mathrm{kHz}$ ) (Greenwood, 1990) but only the middle and basal regions in the gerbil $(\sim 0.1-60 \mathrm{kHz})$ (Müller, 1996). This exocytotic linearization implies that vesicle fusion scales linearly with $\mathrm{Ca}^{2+}$ entry, which in mature high-frequency IHCs has been proposed to depend upon the developmental tightening of the spatial coupling between $\mathrm{Ca}^{2+}$ channels and vesicle release $\mathrm{Ca}^{2+}$ sensors $\left(\mathrm{Ca}^{2+}\right.$-nanodomain coupling) (Brandt et al., 2005; Wong et al., 2014). In this scenario, one or very few $\mathrm{Ca}^{2+}$ channels are sufficient to govern the release of a nearby vesicle (Brandt et al., 2005; Graydon et al., 2011; Zampini et al., 2013). However, an alternative hypothesis is that the linearization is due to developmental changes in the $\mathrm{Ca}^{2+}$ sensor(s) that affect the intrinsic $\mathrm{Ca}^{2+}$ dependence of the synaptic machinery. Although otoferlin is the major $\mathrm{Ca}^{2+}$ sensor in IHCs (Roux et al., 2006; Safieddine et al., 2012), synaptotagmin IV is essential for establishing the linear exocytotic $\mathrm{Ca}^{2+}$ dependence (Johnson et al., 2010), which could arise from its inability to bind $\mathrm{Ca}^{2+}$ in the $\mathrm{C} 2 \mathrm{~A}$ domain (Südhof, 2002). In this second hypothesis, a $\mathrm{Ca}^{2+}$ microdomain coupling scenario could be postulated (Wang and Augustine, 2015). These two synaptic scenarios (i.e., nano- and micro-domain coupling) may indeed coexist within the same auditory organ because low- and high-frequency IHCs are specialized to emphasize mainly the phasic or sustained components of the cell's in vivo receptor potential, respectively (Johnson, 2015).

\section{Nano- versus micro-domain coupling at hair cell ribbon synapses}

In squid giant synapses and mature calyx of Held, synaptic vesicle release is reduced more effectively by BAPTA than by EGTA (Augustine et al., 1991; Fedchyshyn and Wang, 2005; Chen et al., 2015; Nakamura et al., 2015), indicating a nanodomain coupling between $\mathrm{Ca}^{2+}$ channels and exocytotic $\mathrm{Ca}^{2+}$ sensors at mature synapses. However, recent findings have shown that mature hippocampal synapses can also operate via a loose coupling (Vyleta and Jonas, 2014), challenging the view that $\mathrm{Ca}^{2+}$-microdomain mode of $\mathrm{Ca}^{2+}$ signaling is only a characteristic of immature synapses (e.g., Meinrenken et al., 2002; Fedchyshyn and Wang, 2005; Leão and von Gersdorff, 2009; Wang and Augustine, 2015). Instead, it suggests that the vesicle release modality is optimized for 

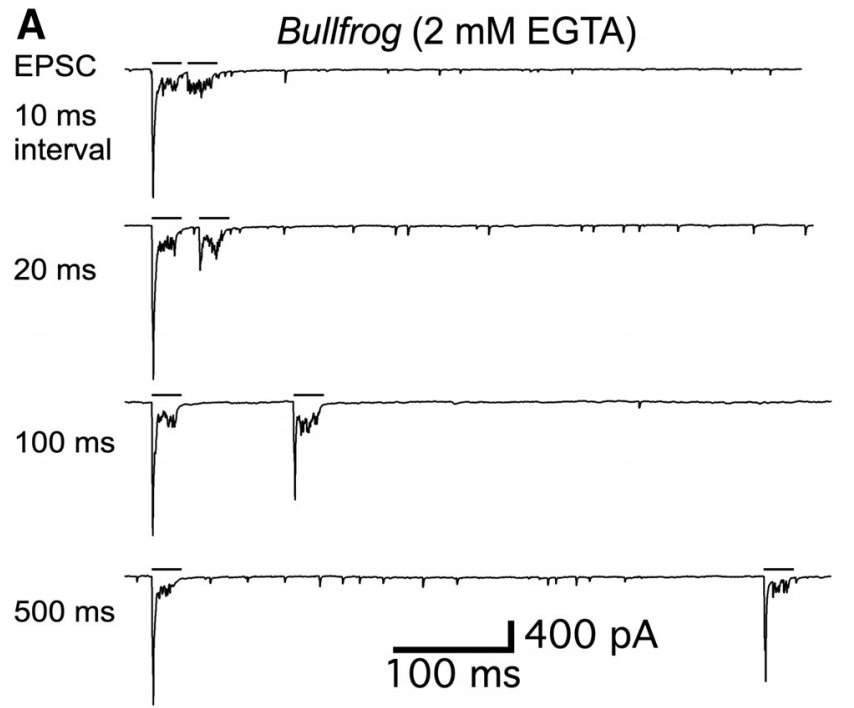

B
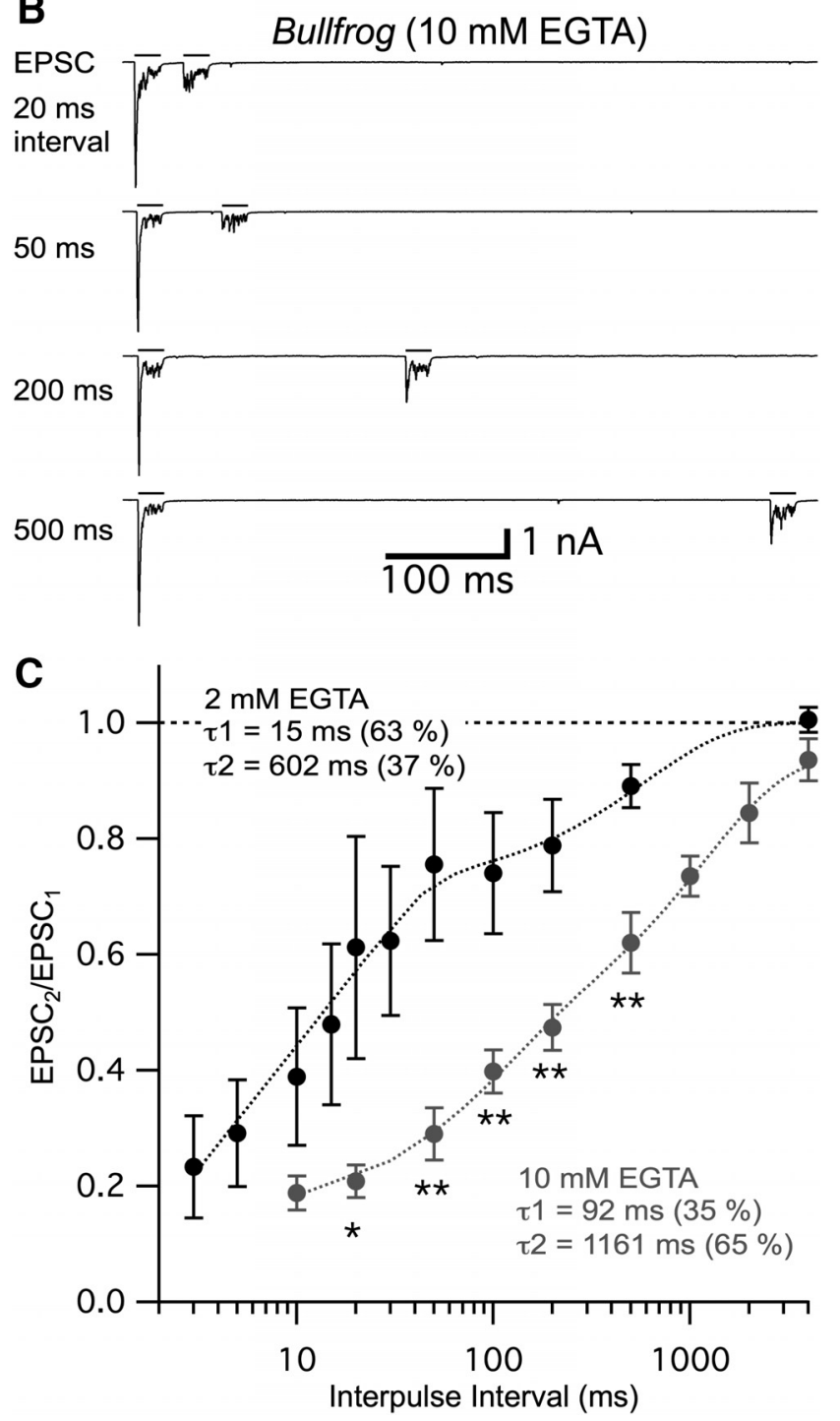

Figure 7. Recovery from paired-pulse depression at bullfrog hair cell synapses is significantly slower with $10 \mathrm{mM}$ EGTA. $\boldsymbol{A}, \boldsymbol{B}$, EPSCs evoked by two depolarizing pulses were obtained by paired recordings from an afferent fiber and an amphibian papilla bullfrog hair cell. The hair cell was depolarized from $-60 \mathrm{mV}$ to $-30 \mathrm{mV}$ for $20 \mathrm{~ms}$ (black bars) with various IPIs (interpulse intervals). The intracellular $\mathrm{Ca}^{2+}$ buffer of the hair cells was 2 mM EGTA $(\boldsymbol{A})$ or $10 \mathrm{mM}$ EGTA specific functional requirements independent from the stage of cell maturation.

Here we found that the RRP of low-frequency hair cell ribbon synapses, in both the mammalian cochlea $(\sim 350 \mathrm{~Hz})$ and bull frog papilla $(<1 \mathrm{kHz})$, were relatively insensitive to EGTA, whereas RRP release from IHCs responding above a few $\mathrm{kHz}$ was either largely reduced $(\sim 2-3 \mathrm{kHz})$ or abolished $(\sim 30 \mathrm{kHz})$. This indicates that the spatial coupling between $\mathrm{Ca}^{2+}$ influx and exocytosis progressively changes along the gerbil auditory organ to cover a wider hearing range $(\sim 0.1-60 \mathrm{kHz})$. Although it has previously been reported that the RRP in mouse IHCs was insensitive to $5 \mathrm{mM}$ EGTA (Moser and Beutner, 2000), perhaps due to the use of high unphysiological extracellular $\mathrm{Ca}^{2+}$, paired recordings from IHCs and auditory afferent fibers in the rat cochlea have demonstrated that the rate of release (EPSCs/ms) was largely reduced by 5 mM EGTA (Goutman and Glowatzki, 2007).

\section{Vesicle recruitment and the $\mathrm{Ca}^{2+}$ dependence of recovery from depression}

We found that apical IHCs tuned to $\sim 350 \mathrm{~Hz}$ in the gerbil recovered fully from paired-pulse depression within $\sim 200 \mathrm{~ms}$ for 50 ms depolarizing pulses and with $0.1 \mathrm{mM}$ EGTA. This recovery rate was slowed by $10 \mathrm{mM}$ EGTA. Similar results were obtained in bullfrog hair cells tuned to lower CF (400-500 Hz; Fig. 7C). The enhanced fast recovery of EPSCs with lower $\mathrm{Ca}^{2+}$ buffering may be due to the greater spread of $\mathrm{Ca}^{2+}$ that speeds the replenishment of vesicles to the ribbon (Van Hook et al., 2014). Recovery from paired-pulse depression was even faster in basal gerbil IHCs $(<100 \mathrm{~ms})$, which is consistent with their microdomain coupling. These recovery rates are extremely rapid compared with that in retinal bipolar cells, which also operate via ribbon synapses (Palmer et al., 2003). This rapid recovery may be an evolutionary adaptation for hair cell ribbon synapses, which are specialized to detect rapid sound signals with short gaps and encode these as firing patterns in the auditory nerve.

\section{$\mathrm{Ca}^{2+}$ influx-secretion coupling and hair cell receptor potential}

The receptor potential of low-frequency IHCs (up to a few $\mathrm{kHz}$ ) has a predominantly phasic component that is phase-locked to the sound frequency and graded in size to the stimulation intensity (Dallos, 1985; Cheatham and Dallos, 1993). The localization of low-frequency sound is accomplished by cells in the auditory brainstem that detect minute time delays in the arrival of the phase-locked afferent activity originating from the two ears $(\sim 10$ $\mu \mathrm{s})$ (Grothe et al., 2010). Such a precise temporal coding has to be preserved at IHC ribbon synapses, and the nanodomain coupling scenario would guarantee rapid and reliable vesicle fusion ( $\mathrm{Ne}$ her, 1998). In the low-frequency cochlear region, a nanodomain coupling would also be required to explain why the time delay in vesicle fusion is similar at all levels of IHC depolarization (i.e.,

$\leftarrow$

(B). The first depolarizing pulse still evokes a large phasic EPSC (EPSC $)_{1}$ ) when $10 \mathrm{mM} \mathrm{EGTA}$ is present in the hair cell. However, the recovery of the phasic component of the second EPSC $\left(\mathrm{EPSC}_{2}\right)$ was significantly slower with $10 \mathrm{mM} \mathrm{EGTA}$. C, Summary of the PPR (EPSC $/ \mathrm{EPSC}_{1}$ ) recovery time course. Two EPSCs were evoked by depolarizing hair cells using a pair of $20 \mathrm{~ms}$ pulse with various IPIs. The $2 \mathrm{mM}$ (black, $n=4-9$ pairs) and $10 \mathrm{mM} \mathrm{EGTA} \mathrm{(gray,} n=5-8$ ) were used as intracellular calcium buffers within hair cells. All the EPSCs were measured after 4 min from the whole-cell break-in to allow for full dialysis with EGTA. Data with $2 \mathrm{mM} \mathrm{EGTA}$ were modified from Cho et al. (2011). PPRs with 20, 50, 100, 200, and 500 ms IPIs were significantly different between 2 mM EGTA and 10 mM EGTA. ${ }^{*} p<0.05$ (unpaired $t$ test). ${ }^{* *} p<0.01$ (unpaired $t$ test). 
A
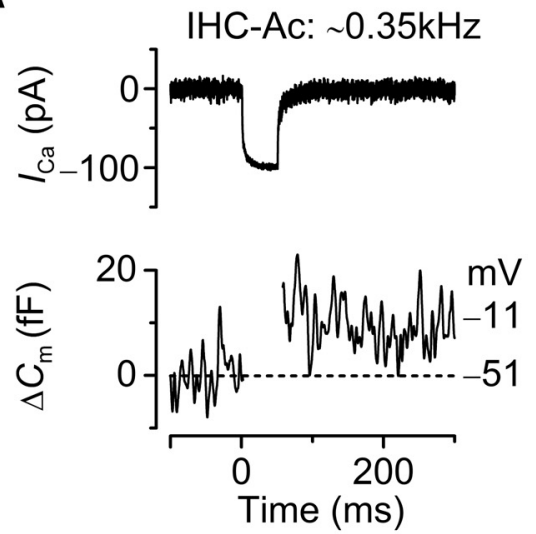

C

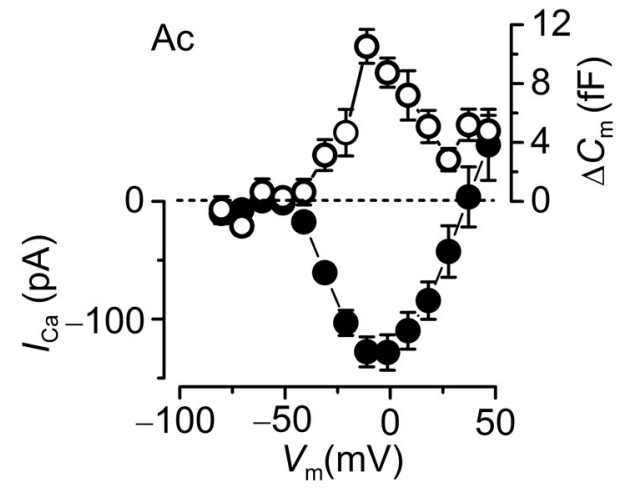

E

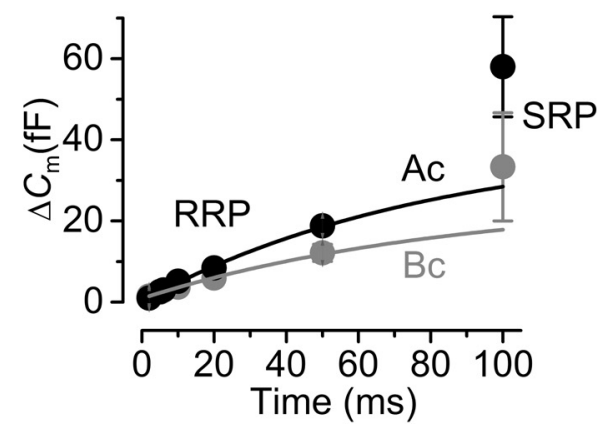

B
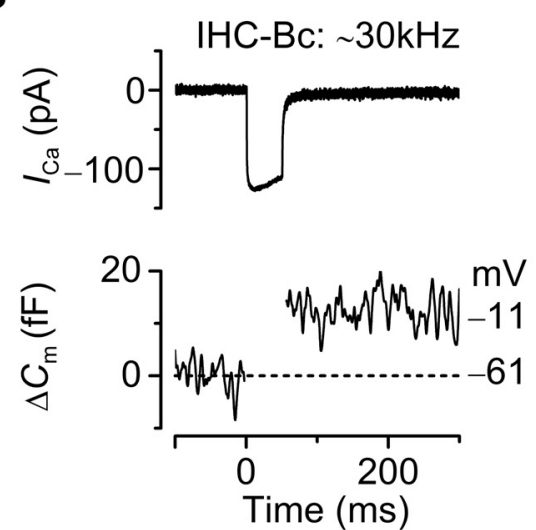

D

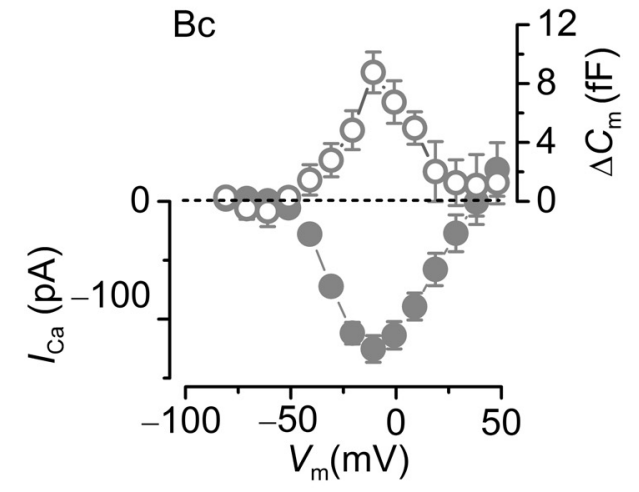

$\mathbf{F}$

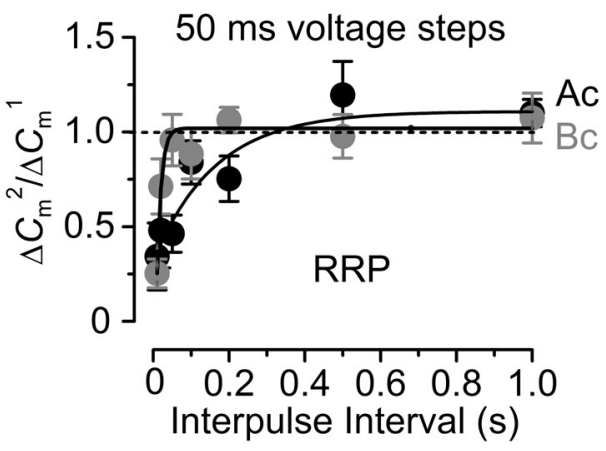

Figure 8. Exocytosis in gerbil IHCs under in vivo resting membrane potential. $\boldsymbol{A}, \boldsymbol{B}, I_{\mathrm{Ca}}$ and $\Delta C_{\mathrm{m}}$ from apical $(\boldsymbol{A})$ and basal $(\boldsymbol{B})$ IHCs in the presence of $1 \mathrm{mM}$ EGTA in the intracellular solution. Voltage protocol is as described in Figure 1, apart from the holding membrane potential, which was $-51 \mathrm{mV}$ for apical and $-61 \mathrm{mV}$ for basal IHCs. For clarity, only responses at the resting membrane potential and the peak of $I_{\mathrm{Ca}}(-11 \mathrm{mV})$ are shown. $\boldsymbol{C}, \boldsymbol{D}$, Average peak $I-V$ and $\Delta C_{\mathrm{m}}-V$ curves in apical (C: $\left.P 19-P 28, n=7\right)$ and basal $(\boldsymbol{D}$ : $P 19-P 28, n=9)$ IHCs. $\boldsymbol{E}$, Average $\Delta C_{\mathrm{m}}$ from apical (black: P19-P28, $n=7$ ) and basal (gray: P19-P28, $n=5$ ) IHCs obtained in response to voltage steps from $2 \mathrm{~ms}$ to $100 \mathrm{~s}$ (to $-11 \mathrm{mV}$ ). Voltage steps up to $50 \mathrm{~ms}$ could be fitted by a single exponential function, which reveals the RRP, and values were as follows: apical, maximum $\Delta C_{\mathrm{m}}=40.1 \pm 14.9 \mathrm{fF}, \tau=81 \pm 38 \mathrm{~ms}$; basal, $\Delta C_{\mathrm{m}}=25.6 \pm 10.5 \mathrm{fF}, \tau=86 \pm 42 \mathrm{~ms}$. Voltage steps to $100 \mathrm{~ms}$ were able to additionally recruit the SRP. $F$, Average $\Delta C_{\mathrm{m}}$ ratio $\left(\Delta C_{\mathrm{m}}{ }^{2} / \Delta C_{\mathrm{m}}{ }^{1}\right.$ : see Fig. $\left.6 A\right)$ from apical (black) and basal (gray) IHCs elicited in response to $50 \mathrm{~ms}$ depolarizing voltage steps to -11 $\mathrm{mV}$ (holding potential of $-51 \mathrm{mV}$ for apical and $-61 \mathrm{mV}$ for basal IHCs) at time 0 and varying the IPI between $10 \mathrm{~ms}$ and $1 \mathrm{~s}$ after the initial step. Data were well fitted with a single exponential function. Note that the time on the x-axis in $\boldsymbol{E}$ indicates the voltage step duration.

stimulus intensity). This property is crucial for the accurate preservation of stimulus timing at all sound intensities and has been suggested to be governed by the single $\mathrm{Ca}^{2+}$ channel properties of first latency and current amplitude (Magistretti et al., 2015). At very low frequencies, the relatively slow depolarizing cycle will allow sufficient $\mathrm{Ca}^{2+}$ influx to saturate the exocytotic $\mathrm{Ca}^{2+}$ sensor, even at low sound intensities. At higher frequencies (up to $\sim 2 \mathrm{kHz}$ ), but still within the limit for phase-locking, the reduced time for $\mathrm{Ca}^{2+}$ influx into IHCs is likely to be insufficient to trigger exocytosis; this could be overcome, in a nanodomain scenario, by the elementary $\mathrm{Ca}^{2+}$ tail currents, where the amplitude and speed of the current are maximized and constant. Indeed, when sinusoidal stimuli of a few hundred hertz were applied to rat IHCs or hair cells from the bullfrog papilla, afferent fibers responded with large EPSCs that occurred more frequently during the repolarizing phase of the cycles (Goutman, 2012; Li et al., 2014), which corresponded to the $\mathrm{Ca}^{2+}$ tail currents.

The filtering characteristics of the hair cell membrane prevents phase-locking $\geq 2-3 \mathrm{kHz}$ (Palmer and Russell, 1986), so receptor potentials are mainly graded and sustained to represent 
sound intensity and stimulus envelope (Russell and Sellick, 1978). High-frequency sound localization is performed by cells that compare interaural-level differences originating from graded responses in $>3 \mathrm{kHz}$ IHCs of each ear (Caird and Klinke, 1983). Therefore, high-frequency IHCs are not designed to follow the frequency components of sound and, as such, do not require the precise timing provided by nanodomain coupling (Matveev et al., 2011), which is likely to be unsuitable for accurate intensity coding. Instead, the changes in the amplitude and kinetic properties of the macroscopic $I_{\mathrm{Ca}}$ with sound intensity are now more relevant (Magistretti et al., 2015), which is more in line with a microdomain coupling reported in this study.

\section{Damage due to loud sounds: why are basal IHCs more susceptible?}

We found that high-frequency IHCs (especially those at $\sim 30$ $\mathrm{kHz}$ ) exhibit a strong block of exocytosis by $10 \mathrm{mM} \mathrm{EGTA}$, indicating that these cells cannot have a large endogenous $\mathrm{Ca}^{2+}$ buffering capacity, because it would severely impair transmitter release. This was confirmed by the estimated intracellular $\mathrm{Ca}^{2+}$ buffer expressed as an equivalent of EGTA concentration (Fig. 3). Indeed, a triple knock-out mouse for different $\mathrm{Ca}^{2+}$-binding proteins did not reveal changes in synaptic sound encoding (Pangršič et al., 2015), suggesting that high-frequency IHCs may thus have a relatively low concentration of $\mathrm{Ca}^{2+}$-binding proteins. By contrast, low-frequency tuned bullfrog hair cells have an estimated $8 \mathrm{mM}$ of high-affinity $\mathrm{Ca}^{2+}$-binding sites on small mobile proteins (e.g., parvalbumin and calbindin) (Heller et al., 2002), suggesting that their endogenous $\mathrm{Ca}^{2+}$ buffering capacity may be more equivalent to $10 \mathrm{mM}$ EGTA.

High-frequency hair cell synapses are also particularly vulnerable to damage during loud noises and aging, which has been shown to lead to the loss of both IHC synaptic ribbons (Kujawa and Liberman, 2009; Kujawa and Liberman, 2015) and lowspontaneous rate afferent fibers (Furman et al., 2013). We thus propose that low-frequency IHCs may express higher concentrations of $\mathrm{Ca}^{2+}$-binding proteins, which will not block exocytosis but may confer neuroprotection against excessive $\mathrm{Ca}^{2+}$ influx during prolonged stimulation. By contrast, the low $\mathrm{Ca}^{2+}$ buffer capacity in high-frequency basal IHCs, which is required for their graded release, will make them more prone to $\mathrm{Ca}^{2+}$-induced cytotoxicity. A tonotopic gradient in $\mathrm{Ca}^{2+}$-binding protein expression has been reported in auditory hair cells (Hackney et al., 2003, 2005; Patel et al., 2012), which may facilitate a frequencydependent tuning of exocytosis in some animal species (Schnee et al., 2005; Rutherford and Roberts, 2006; Patel et al., 2012).

\section{References}

Adler EM, Augustine GJ, Duffy SN, Charlton MP (1991) Alien intracellular calcium chelators attenuate neurotransmitter release at the squid giant synapse. J Neurosci 11:1496-1507. Medline

Augustine GJ, Adler EM, Charlton MP (1991) The calcium signal for transmitter secretion from presynaptic nerve terminals. Ann N Y Acad Sci 635:365-381. CrossRef Medline

Borst JG, Sakmann B (1996) Calcium influx and transmitter release in a fast CNS synapse. Nature 383:431-434. CrossRef Medline

Brandt A, Khimich D, Moser T (2005) Few $\mathrm{Ca}_{\mathrm{V}} 1.3$ channels regulate the exocytosis of a synaptic vesicle at the hair cell ribbon synapse. J Neurosci 25:11577-11585. CrossRef Medline

Bucurenciu I, Kulik A, Schwaller B, Frotscher M, Jonas P (2008) Nanodomain coupling between $\mathrm{Ca}^{2+}$ channels and $\mathrm{Ca}^{2+}$ sensors promotes fast and efficient transmitter release at a cortical GABAergic synapse. Neuron 57:536-545. CrossRef Medline

Caird D, Klinke R (1983) Processing of binaural stimuli by cat superior olivary complex neurons. Exp Brain Res 52:385-399. Medline
Cheatham MA, Dallos P (1993) Longitudinal comparisons of IHC ac and dc receptor potentials recorded from the guinea pig cochlea. Hear Res 68: 107-114. CrossRef Medline

Chen Z, Das B, Nakamura Y, DiGregorio DA, Young SM Jr (2015) $\mathrm{Ca}^{2+}$ channel to synaptic vesicle distance accounts for the readily releasable pool kinetics at a functionally mature auditory synapse. J Neurosci 35 : 2083-2100. CrossRef Medline

Cho S, von Gersdorff H (2014) Proton-mediated block of $\mathrm{Ca}^{2+}$ channels during multivesicular release regulates short-term plasticity at an auditory hair cell synapse. J Neurosci 34:15877-15887. CrossRef Medline

Cho S, Li GL, von Gersdorff H (2011) Recovery from short-term depression and facilitation is ultrafast and $\mathrm{Ca}^{2+}$ dependent at auditory hair cell synapses. J Neurosci 31:5682-5692. CrossRef Medline

Coggins M, Zenisek D (2009) Evidence that exocytosis is driven by calcium entry through multiple calcium channels in goldfish retinal bipolar cells. J Neurophysiol 101:2601-2619. CrossRef Medline

Crawford AC, Fettiplace R (1980) The frequency selectivity of auditory nerve fibres and hair cells in the cochlea of the turtle. J Physiol 306:79125. CrossRef Medline

Dallos P (1985) Response characteristics of mammalian cochlear hair cells. J Neurosci 5:1591-1608. Medline

Ehret G (1975) Masked auditory thresholds, critical ratios, and scales of the basilar membrane of the housemouse (Mus musculus). J Comp Physiol 103:329-341. CrossRef

Fedchyshyn MJ, Wang LY (2005) Developmental transformation of the release modality at the calyx of Held synapse. J Neurosci 25:4131-4140. CrossRef Medline

Fettiplace R, Fuchs PA (1999) Mechanisms of hair cell tuning. Annu Rev Physiol 61:809-834. CrossRef Medline

Frank T, Rutherford MA, Strenzke N, Neef A, Pangršič T, Khimich D, Fejtova A, Gundelfinger ED, Liberman MC, Harke B, Bryan KE, Lee A, Egner A, Riedel D, Moser T (2010) Bassoon and the synaptic ribbon organize $\mathrm{Ca}^{2+}$ channels and vesicles to add release sites and promote refilling Neuron 68:724-738. CrossRef

Fuchs PA (2005) Time and intensity coding at the hair cell's ribbon synapse. J Physiol 566:7-12. CrossRef Medline

Furman AC, Kujawa SG, Liberman MC (2013) Noise-induced cochlear neuropathy is selective for fibers with low spontaneous rates. J Neurophysiol 110:577-586. CrossRef Medline

Gillis KD (2000) Admittance-based measurement of membrane capacitance using the EPC-9 patch-clamp amplifier. Pflugers Arch 439:655664. CrossRef Medline

Glowatzki E, Fuchs PA (2002) Transmitter release at the hair cell ribbon synapse. Nat Neurosci 5:147-154. CrossRef Medline

Goutman JD, Glowatzki E (2011) Short-term facilitation modulates size and timing of the synaptic response at the inner hair cell ribbon synapse. J Neurosci 31:7974-7981. CrossRef Medline

Goutman JD (2012) Transmitter release from cochlear hair cells is phase locked to cyclic stimuli of different intensities and frequencies. J Neurosci 32:17025-17035a. CrossRef Medline

Goutman JD, Glowatzki E (2007) Time course and calcium dependence of transmitter release at a single ribbon synapse. Proc Natl Acad Sci U S A 104:16341-16346. CrossRef Medline

Graydon CW, Cho S, Li GL, Kachar B, von Gersdorff H (2011) Sharp Ca ${ }^{2+}$ nanodomains beneath the ribbon promote highly synchronous multivesicular release at hair cell synapses. J Neurosci 31:16637-16650. CrossRef Medline

Graydon CW, Cho S, Diamond JS, Kachar B, von Gersdorff H, Grimes WN (2014) Specialized postsynaptic morphology enhances neurotransmitter dilution and high-frequency signaling at an auditory synapse. J Neurosci 34:8358-8372. CrossRef Medline

Greenwood DD (1990) A cochlear frequency-position function for several species: 29 years later. J Acoust Soc Am 87:2592-2605. CrossRef Medline

Grothe B, Pecka M, McAlpine D (2010) Mechanisms of sound localization in mammals. Physiol Rev 90:983-1012. CrossRef Medline

Hackney CM, Mahendrasingam S, Jones EM, Fettiplace R (2003) The distribution of calcium buffering proteins in the turtle cochlea. J Neurosci 23:4577-4589. Medline

Hackney CM, Mahendrasingam S, Penn A, Fettiplace R (2005) The concentrations of calcium buffering proteins mammalian cochlear hair cells. J Neurosci 25:7867-7875. CrossRef Medline

Heil P, Peterson AJ (2017) Spike timing in auditory-nerve fibers during 
spontaneous activity and phase locking. Synapse 71:5-36. CrossRef Medline

Heller S, Bell AM, Denis CS, Choe Y, Hudspeth AJ (2002) Parvalbumin 3 is an abundant $\mathrm{Ca}^{2+}$ buffer in hair cells. J Assoc Res Otolaryngol 3:488498. CrossRef Medline

Johnson SL (2015) Membrane properties specialize mammalian inner hair cells for frequency or intensity encoding. Elife 4:e08177. Medline

Johnson SL, Marcotti W (2008) Biophysical properties of $\mathrm{Ca}_{\mathrm{V}} 1.3$ calcium channels in gerbil inner hair cells. J Physiol 586:1029-1042. CrossRef Medline

Johnson SL, Marcotti W, Kros CJ (2005) Increase in efficiency and reduction in $\mathrm{Ca}^{2+}$ dependence of exocytosis during development of mouse inner hair cells. J Physiol 563:177-191. CrossRef Medline

Johnson SL, Adelman JP, Marcotti W (2007) Disruption of spontaneous action potential activity in inner hair cells of SK2 knockout mice prevents the normal development of exocytotic machinery. J Physiol 583:631-646. CrossRef Medline

Johnson SL, Forge A, Knipper M, Münkner S, Marcotti W (2008) Tonotopic variation in the calcium dependence of neurotransmitter release and vesicle pool replenishment at mammalian auditory ribbon synapses. J Neurosci 28:7670-7678. CrossRef Medline

Johnson SL, Franz C, Knipper M, Marcotti W (2009) Functional maturation of the exocytotic machinery at gerbil hair cell ribbon synapses. J Physiol 587:1715-1726. CrossRef Medline

Johnson SL, Franz C, Kuhn S, Furness DN, Rüttiger L, Münkner S, Rivolta MN, Seward EP, Herschman HR, Engel J, Knipper M, Marcotti W (2010) Synaptotagmin IV determines the linear $\mathrm{Ca}^{2+}$ dependence of vesicle fusion at auditory ribbon synapses. Nat Neurosci 13:45-52. CrossRef Medline

Johnson SL, Beurg M, Marcotti W, Fettiplace R (2011) Prestin-driven cochlear amplification is not limited by the outer hair cell membrane time constant. Neuron 70:1143-1154. CrossRef Medline

Keen EC, Hudspeth AJ (2006) Transfer characteristics of the hair cell's afferent synapse. Proc Natl Acad Sci U S A 103:5537-5542. CrossRef Medline

Kros CJ, Ruppersberg JP, Rüsch A (1998) Expression of a potassium current in inner hair cells during development of hearing in mice. Nature 394: 281-284. CrossRef Medline

Kujawa SG, Liberman MC (2009) Adding insult to injury: cochlear nerve degeneration after "temporary" noise-induced hearing loss. J Neurosci 29:14077-14085. CrossRef Medline

Kujawa SG, Liberman MC (2015) Synaptopathy in the noise-exposed and aging cochlea: primary neural degeneration in acquired sensorineural hearing loss. Hear Res 330:191-199. CrossRef Medline

Leão RM, von Gersdorff H (2009) Synaptic vesicle pool size, release probability and synaptic depression are sensitive to $\mathrm{Ca}^{2+}$ buffering capacity in the developing rat calyx of Held. Braz J Med Biol Res 42:94-104. CrossRef Medline

Lenzi D, Runyeon JW, Crum J, Ellisman MH, Roberts WM (1999) Synaptic vesicle populations in saccular hair cells reconstructed by electron tomography. J Neurosci 19:119-132. Medline

Lewis E, Leverenz E, Koyama H (1982) The tonotopic organization of the bullfrog amphibian papilla, an auditory organ lacking a basilar membrane. J Comp Physiol A Neuroethol Sens Neural Behav Physiol Neuroethol Sens Neural Behav Physiol 145:437-445. CrossRef

Li GL, Keen E, Andor-Ardó D, Hudspeth AJ, von Gersdorff H (2009) The unitary event underlying multiquantal EPSCs at a hair cell's ribbon synapse. J Neurosci 29:7558-7568. CrossRef Medline

Li GL, Cho S, von Gersdorff H (2014) Phase-locking precision is enhanced by multiquantal release at an auditory hair cell ribbon synapse. Neuron 83:1404-1417. CrossRef Medline

Lindau M, Neher E (1988) Patch-clamp techniques for time-resolved capacitance measurements in single cells. Pflugers Arch 411:137-146. CrossRef Medline

Magistretti J, Spaiardi P, Johnson SL, Masetto S (2015) Elementary properties of $\mathrm{Ca}^{2+}$ channels and their influence on multivesicular release and phase-locking at auditory hair cell ribbon synapses. Front Cell Neurosci 9:123. CrossRef Medline

Marcotti W, Johnson SL, Holley MC, Kros CJ (2003) Developmental changes in the expression of potassium currents of embryonic, neonatal and mature mouse inner hair cells. J Physiol 548:383-400. CrossRef Medline
Matthews G, Fuchs P (2010) The diverse roles of ribbon synapses in sensory neurotransmission. Nat Rev Neurosci 11:812-822. CrossRef Medline

Matveev V, Bertram R, Sherman A (2011) Calcium cooperativity of exocytosis as a measure of $\mathrm{Ca}^{2+}$ channel domain overlap. Brain Res 1398:126-138. CrossRef Medline

Meinrenken CJ, Borst JG, Sakmann B (2002) Calcium secretion coupling at calyx of held governed by nonuniform channel-vesicle topography. J Neurosci 22:1648-1667. Medline

Meyer AC, Frank T, Khimich D, Hoch G, Riedel D, Chapochnikov NM, Yarin YM, Harke B, Hell SW, Egner A, Moser T (2009) Tuning of synapse number, structure and function in the cochlea. Nat Neurosci 12:444-453. CrossRef Medline

Moser T, Beutner D (2000) Kinetics of exocytosis and endocytosis at the cochlear inner hair cell afferent synapse of the mouse. Proc Natl Acad Sci U S A 97:883-888. CrossRef Medline

Müller M (1996) The cochlear place-frequency map of the adult and developing Mongolian gerbil. Hear Res 94:148-156. CrossRef Medline

Nakamura Y, Harada H, Kamasawa N, Matsui K, Rothman JS, Shigemoto R, Silver RA, DiGregorio DA, Takahashi T (2015) Nanoscale distribution of presynaptic $\mathrm{Ca}^{2+}$ channels and its impact on vesicular release during development. Neuron 85:145-158. CrossRef Medline

Naraghi M, Neher E (1997) Linearized buffered $\mathrm{Ca}^{2+}$ diffusion in microdomains and its implications for calculation of $\left[\mathrm{Ca}^{2+}\right]$ at the mouth of a calcium channel. J Neurosci 17:6961-6973. Medline

Neher E (1998) Vesicle pools and $\mathrm{Ca}^{2+}$ microdomains: new tools for understanding their roles in neurotransmitter release. Neuron 20:389-399. CrossRef Medline

Nouvian R (2007) Temperature enhances exocytosis efficiency at the mouse inner hair cell ribbon synapse. J Physiol 584:535-542. CrossRef Medline

Palmer AR, Russell IJ (1986) Phase-locking in the cochlear nerve of the guinea-pig and its relation to the receptor potential of inner hair-cells. Hear Res 24:1-15. CrossRef Medline

Palmer MJ, Hull C, Vigh J, von Gersdorff H (2003) Synaptic cleft acidification and modulation of short-term depression by exocytosed protons in retinal bipolar cells. J Neurosci 23:11332-11341. Medline

Pangršič T, Gabrielaitis M, Michanski S, Schwaller B, Wolf F, Strenzke N, Moser T (2015) EF-hand protein $\mathrm{Ca}^{2+}$ buffers regulate $\mathrm{Ca}^{2+}$ influx and exocytosis in sensory hair cells. Proc Natl Acad Sci U S A 112:E1028E1037. CrossRef Medline

Patel SH, Salvi JD, Ó Maoiléidigh D, Hudspeth AJ (2012) Frequencyselective exocytosis by ribbon synapses of hair cells in the bullfrog's amphibian papilla. J Neurosci 32:13433-13438. CrossRef Medline

Pitchford S, Ashmore JF (1987) An electrical resonance in hair cells of the amphibian papilla of the frog Rana temporaria. Hear Res 27:75-83. CrossRef Medline

Platzer J, Engel J, Schrott-Fischer A, Stephan K, Bova S, Chen H, Zheng H, Striessnig J (2000) Congenital deafness and sinoatrial node dysfunction in mice lacking class D L-type $\mathrm{Ca}^{2+}$ channels. Cell 102:89-97. CrossRef Medline

Roberts WM, Jacobs RA, Hudspeth AJ (1990) Colocalization of ion channels involved in frequency selectivity and synaptic transmission at presynaptic active zones of hair cells. J Neurosci 10:3664-3684. Medline

Rose JE, Brugge JF, Anderson DJ, Hind JE (1967) Phase-locked response to low-frequency tones in single auditory nerve fibers of the squirrel monkey. J Neurophysiol 30:769-793. Medline

Roux I, Safieddine S, Nouvian R, Grati M, Simmler MC, Bahloul A, Perfettini I, Le Gall M, Rostaing P, Hamard G, Triller A, Avan P, Moser T, Petit C (2006) Otoferlin, defective in a human deafness form, is essential for exocytosis at the auditory ribbon synapse. Cell 127:277-289. CrossRef Medline

Russell IJ, Sellick PM (1978) Intracellular studies of hair cells in the mammalian cochlea. J Physiol 284:261-290. CrossRef Medline

Rutherford MA, Roberts WM (2006) Frequency selectivity of synaptic exocytosis in frog saccular hair cells. Proc Natl Acad Sci U S A 103:28982903. CrossRef Medline

Safieddine S, El-Amraoui A, Petit C (2012) The auditory hair cell ribbon synapse: from assembly to function. Annu Rev Neurosci 35:509-528. CrossRef Medline

Schmidt H, Brachtendorf S, Arendt O, Hallermann S, Ishiyama S, Bornschein G, Gall D, Schiffmann SN, Heckmann M, Eilers J (2013) Nanodomain coupling at an excitatory cortical synapse. Curr Biol 23:244-249. CrossRef Medline 
Schnee ME, Lawton DM, Furness DN, Benke TA, Ricci AJ (2005) Auditory hair cell-afferent fiber synapses are specialized to operate at their best frequencies. Neuron 47:243-254. CrossRef Medline

Stanley EF (2016) The nanophysiology of fast transmitter release. Trends Neurosci 39:183-197. CrossRef Medline

Südhof TC (2002) Synaptotagmins: why so many? J Biol Chem 277:7629_ 7632. CrossRef Medline

Van Hook MJ, Parmelee CM, Chen M, Cork KM, Curto C, Thoreson WB (2014) Calmodulin enhances ribbon replenishment and shapes filtering of synaptic transmission by cone photoreceptors. J Gen Physiol 144:357378. CrossRef Medline

Vincent PF, Bouleau Y, Safieddine S, Petit C, Dulon D (2014) Exocytotic machineries of vestibular type I and cochlear ribbon synapses display similar intrinsic otoferlin-dependent $\mathrm{Ca}^{2+}$ sensitivity but a different coupling to $\mathrm{Ca}^{2+}$ channels. J Neurosci 34:10853-10869. CrossRef Medline

Vyleta NP, Jonas P (2014) Loose coupling between $\mathrm{Ca}^{2+}$ channels and release sensors at a plastic hippocampal synapse. Science 343:665-670. CrossRef Medline
Wang LY, Augustine GJ (2015) Presynaptic nanodomains: a tale of two synapses. Front Cell Neurosci 8:455. CrossRef Medline

Wangemann P, Schacht J (1996) Homeostatic mechanisms in the cochlea. In: The cochlea (Dallos P, Popper A, Fay R, eds), pp 130-185. New York: Springer.

Wong AB, Rutherford MA, Gabrielaitis M, Pangršič T, Göttfert F, Frank T, Michanski S, Hell S, Wolf F, Wichmann C, Moser T (2014) Developmental refinement of hair cell synapses tightens the coupling of $\mathrm{Ca}^{2+}$ influx to exocytosis. EMBO J 33:247-264. CrossRef Medline

Zampini V, Johnson SL, Franz C, Lawrence ND, Münkner S, Engel J, Knipper M, Magistretti J, Masetto S, Marcotti W (2010) Elementary properties of CaV1.3 $\mathrm{Ca}^{2+}$ channels expressed in mouse cochlear inner hair cells. J Physiol 588:187-199. CrossRef Medline

Zampini V, Johnson SL, Franz C, Knipper M, Holley MC, Magistretti J, Masetto S, Marcotti W (2013) Burst activity and ultrafast activation kinetics of $\mathrm{Ca}_{\mathrm{V}} 1.3 \mathrm{Ca}^{2+}$ channels support presynaptic activity in adult gerbil hair cell ribbon synapses. J Physiol 591:3811-3820. CrossRef Medline 